Submitted, accepted and published by Elsevier, Molecular Phylogenetics and Evolution 107: 142-151 (2017).

This manuscript version is made available under the CC-BY-NC-ND 4.0 license http:// creativecommons.org/licenses/by-nc-nd/4.0/

\title{
Beyond Conus: phylogenetic relationships of Conidae based on
}

\section{complete mitochondrial genomes}

Juan E. Uribe ${ }^{1}$, Nicolas Puillandre ${ }^{2} \&$ Rafael Zardoya ${ }^{1^{*}}$

\footnotetext{
${ }^{1}$ Museo Nacional de Ciencias Naturales (MNCN-CSIC), José Gutiérrez Abascal 2, 28006, Madrid, Spain

${ }^{2}$ Institut de Systématique, Évolution, Biodiversité ISYEB - UMR 7205 - CNRS, MNHN, UPMC, EPHE, Muséum National d'Histoire Naturelle, Sorbonne Universités, 43 rue Cuvier, CP26, F-75005, Paris, France.
}

*Corresponding author ( $\underline{\text { rafaz @ mncn.csic.es })}$ 


\section{Abstract}

Understanding how the extraordinary taxonomic and ecological diversity of cone snails (Caenogastropoda: Conidae) evolved requires a statistically robust phylogenetic framework, which thus far is not available. While recent molecular phylogenies have been able to distinguish several deep lineages within the family Conidae, including the genera Profundiconus, Californiconus, Conasprella, and Conus (and within this one, several subgenera), phylogenetic relationships among these genera remain elusive. Moreover, the possibility that additional deep lineages may exist within the family is open. Here, we reconstructed with probabilistic methods a molecular phylogeny of Conidae using the newly sequenced complete or nearly complete (mt) mitochondrial genomes of the following nine species that represent all main Conidae lineages and potentially new ones: Profundiconus teramachii, Californiconus californicus, Conasprella wakayamaensis, Lilliconus sagei, Pseudolilliconus traillii, Conus (Kalloconus) venulatus, Conus (Lautoconus) ventricosus, Conus (Lautoconus) hybridus, and Conus (Eugeniconus) nobilis. To test the monophyly of the family, we also sequenced the nearly complete mt genomes of the following three species representing closely related conoidean families: Benthomangelia sp. (Mangeliidae), Tomopleura sp. (Borsoniidae), and Glyphostoma sp. (Clathurellidae). All newly sequenced conoidean $\mathrm{mt}$ genomes shared a relatively constant gene order with rearrangements limited to tRNA genes. The reconstructed phylogeny recovered with high statistical support the monophyly of Conidae and phylogenetic relationships within the family. The genus Profundiconus was placed as sister to the remaining genera. Within these, a clade including Californiconus and Lilliconus + Pseudolilliconus was the sister group of Conasprella to the exclusion of Conus. The phylogeny included a new lineage whose relative phylogenetic position was unknown (Lilliconus) and uncovered thus far hidden 
diversity within the family (Pseudolilliconus). Moreover, reconstructed phylogenetic relationships allowed inferring that the peculiar diet of Californiconus based on worms, mollusks, crustaceans and fish is derived, and reinforce the hypothesis that the ancestor of Conidae was a worm hunter. A chronogram was reconstructed under an uncorrelated relaxed molecular clock, which dated the origin of the family shortly after the Cretaceous-Tertiary boundary (about 59 million years ago) and the divergence among main lineages during the Paleocene and the Eocene (56-30 million years ago).

Key words: Conidae, Californiconus, Conasprella, Lilliconus, Conus, mtDNA. 


\section{Introduction}

With more than 830 described species (WoRMS, 2016), cone snails (Family Conidae, Fleming, 1822 sensu lato) constitute a major component of the biodiversity of tropical and subtropical oceans (Tucker and Tenorio, 2013). The species diversity of cones is highest in the Indo-West Pacific region (Röckel et al., 1995) but notably about $10 \%$ of the species radiated in the Cape Verde archipelago (Cunha et al., 2005; Duda and Rolan, 2005). While some species show widespread distributions (e.g., Conus litteratus Linnaeus, 1758 throughout the Indo-West Pacific region), others are narrowly restricted to an island or a bay (e.g., Conus verdensis Trovão, 1979 from Santiago Island in Cape Verde). Cones are found from deep waters to the intertidal zone, associated to rocky shores, coral reefs, and sandy bottoms (Kohn, 1959). These marine gastropods are predatory carnivores feeding mostly on marine worms, snails and fishes (Duda et al., 2001), and have evolved a sophisticated mechanism to capture preys, which are paralyzed thanks to harpoon-like radular teeth coated with a cocktail of toxins produced in a venom gland (Olivera, 2002). Interestingly, recent transcriptomic studies have shown that predation- and defense-evoked venoms are produced in the distal and proximal regions of the venom duct, respectively (Dutertre et al., 2014; Prashanth et al., 2016). Moreover, conotoxins are of important medical and pharmaceutical interest since they are potent and have very specific inhibitors of ion channels in the human brain (Terlau and Olivera, 2004). Reconstructing a statistically robust phylogeny of Conidae is mandatory for understanding how the great species diversity of the family was generated and addressing other important evolutionary open questions in the group such as the origin of the different diet specializations or how did predation and defense venoms appeared and evolved (Duda et al., 2001; Puillandre et al., 2014a). Moreover, current discovery of pharmacologically important conotoxins could be enhanced and improved by using a concerted discovery strategy that takes into account robustly inferred phylogenetic relationships to target most divergent and poorly studied groups (Holford et al., 2009; Puillandre and Holford, 2010). 
All cones share a typical conical shell of different sizes ( $\mathrm{mm}$ to about $20 \mathrm{~cm}$ ), often brightly colored, and with diverse banding patterns that is highly appreciated by collectors (Tucker and Tenorio, 2013). The inner walls of the shell are re-absorbed during growth, and this is considered a synapomorphy of the family Conidae (Tucker and Tenorio, 2009). In general, the shell is helpful for species identification but has limited utility for discrimination of higher taxonomic levels, at which other characters such as the shape of the radula and DNA sequences are used (Tucker and Tenorio, 2009; Puillandre et al., 2014a). The family Conidae belongs to the superfamily Conoidea (Caenogastropoda: Neogastropoda) together with closely related families such as e.g., Conorbidae, Raphitomidae, Mangeliidae, Borsoniidae, Clathurellidae, and Mitromorphidae (See Puillandre et al. 2011, and references therein). Traditionally, most authors assumed that the family Conidae contained only the genus Conus (e.g., Röckel et al., 1995; but see Cotton, 1945; Walls, 1978; Da Motta, 1991; Taylor et al., 1993). However, two recent studies have proposed considerable changes to the classification of the family. One study (Tucker and Tenorio, 2009) was based on cladistic analysis of radular teeth and shell characters and proposed to recognize some previously introduced genera in addition to Conus, to raise some previously known subgenera to the genus level, and to erect completely new genera. The proposed classification distinguished up to four living families (including Conidae, Conilithidae, Conorbidae, and Taranteconidae) and 86 extant genera. Later, Conorbidae was tentatively maintained as a separate family (Bouchet et al., 2011) and species within Taranteconidae were found to be closely related to Conus (Stephanoconus) (Watkins et al., 2010). The other study (Puillandre et al., 2014a) was based on probabilistic analyses of three partial mitochondrial (mt) genes and included 330 species belonging to Conidae, Conilithidae and Taranteconidae sensu Tucker and Tenorio (2009). The presence of several deep lineages within the analyzed taxa prompted for a new taxonomic classification (that we follow here naming the subgenus only the first time) with a single family Conidae, 
which included four genera, namely Californiconus, Profundiconus, Conasprella, and Conus (Puillandre et al., 2014b). The latter two genera were further subdivided into 11 and 60 subgenera, respectively (Puillandre et al., 2014b). The reconstructed phylogeny showed that Profundiconus was the sister group of the remaining Conidae, although without support (and thus questioning the limits of the family; Puillandre et al., 2014a). Within the remaining taxa, Californiconus was the sister group of Conasprella and Conus (Puillandre et al., 2014a). Therefore, the genera Conus and Conasprella sensu Puillandre et al. (2014b) more or less corresponded to the families Conidae and Conilithidae sensu Tucker and Tenorio (2009), respectively. However, the genera Profundiconus and Californiconus were excluded from other Conilithidae (Conasprella) (Puillandre et al., 2014b). Besides that, major lineages within Conasprella and Conus were highly congruent between both studies, only differing in their subgeneric (Puillandre et al., 2014b) or generic (Tucker and Tenorio, 2009) status, and on the placement of some species for which there was no radula and/or DNA data available and that were ascribed based on shell characters only (Tucker and Tenorio, 2009). Moreover, the new molecular phylogeny was confirming previous ones (Duda and Kohn, 2005; Biggs et al., 2010) that had already distinguished Conus californicus, a "Small Major Clade" (Conasprella) and a "Large Major Clade (Conus). In addition, different lineages within Conasprella (Kraus et al., 2012) and Conus (Espiritu et al., 2001; Nam et al., 2009; Kraus et al., 2011) were also recovered in several previous molecular phylogenies.

Here, we aimed to confirm the main deep lineages reported within Conidae (sensu Puillandre et al., 2014b) and in particular to define the phylogenetic relationships between these main deep lineages, which were mostly unresolved in published phylogenies (e.g., Puillandre et al., 2014a). To achieve these goals, we used complete or almost complete (without control region) mt genome sequence data, which have proven useful in recovering internal nodes with high support at this level of divergence or higher in other gastropods (Grande et al., 2008; White et al., 2011; Uribe et al., 2016). 
Thus far, the only complete mt genomes available for Conidae are those of Conus (Cylinder) textile (Bandyopadhyay et al., 2008); Conus (Gastridium) tulipa (Chen et al., 2015); Conus (Lautoconus) borgesi (Cunha et al., 2009); Conus (Splinoconus) tribblei (Barghi et al., 2015); and Conus (Pionoconus) consors (Brauer et al., 2012). No complete mt genomes are available for other cone snails genera and for related families within Conoidea, and the closest conoideans available are Xenuroturris cerithiformis (Turridae; (Bandyopadhyay et al., 2006), Fusiturris similis (Clavatulidae; (Cunha et al., 2009), and Oxymeris dimidiata (Terebridae; (Cunha et al., 2009), which some authors place in a different superfamily, Turroidea (Tucker and Tenorio, 2009). Therefore, we sequenced mtDNAs of several species representing the main lineages of Conidae (Profundiconus, Californiconus, Conasprella, and Conus), as well as closely related conoidean families (Mangeliidae, Clathurellidae, and Borsoniidae). In addition, we sequenced the mt genomes of two highly divergent species of cones that may represent additional genera (Lilliconus and Pseudolilliconus). Our aims were: (1) to confirm the previously identified main lineages within cone snails and eventually identify new ones; (2) to reconstruct a robust phylogeny of Conidae that could be used as framework for further evolutionary studies; (3) to assess whether there have been major rearrangements of the mtDNA genome organization among the analyzed conoidean families, and (4) to date main cladogenetic events within Conidae.

\section{Materials and methods}

\subsection{Samples and DNA extraction}

The complete list of species analyzed in this study corresponding to families Conidae, Borsoniidae, Mangeliidae and Clathurellidae, is shown in Table 1, along with their respective sampling localities and museum vouchers. Specimens from the MNHN were either found in old collections or newly collected during several recent expeditions (Atimo Vatae in Madagascar, Papua Niugini and Kavieng in Papua New-Guinea). All 
samples were stored in ethanol $100 \%$ and total genomic DNA was isolated from up to 30-50 $\mathrm{mg}$ of foot tissue following a standard phenol-chloroform extraction.

\subsection{PCR amplification and sequencing}

Complete or nearly complete (without the control region; see results and discussion) $\mathrm{mt}$ genomes were amplified through long PCR using different combinations of conserved primers newly designed in $\mathrm{mt} \operatorname{coxl} \mathrm{l} \operatorname{cox} 3, \mathrm{rrnL}$ and $\mathrm{trn} F$ genes (Supplementary material 1). The long PCR reactions contained $2.5 \mu \mathrm{l}$ of $10 \times \mathrm{LA} \mathrm{Buffer} \mathrm{II}\left(\mathrm{Mg}^{+2}\right.$ plus $), 3 \mu \mathrm{l}$ of dNTPs (2.5 mM each), $0.5 \mu \mathrm{l}$ of each primer $(10 \mathrm{mM}), 0.5-1 \mu \mathrm{l}(10-40 \mathrm{ng})$ of template DNA, $0.2 \mu 1$ TaKaRa LA Taq DNA polymerase ( 5 units/ $\mu$ ), and sterilized distilled water up to $25 \mu \mathrm{l}$. The following PCR conditions were used: initial denaturing step at $94^{\circ} \mathrm{C}$ for $60 \mathrm{~s} ; 45$ cycles of denaturing at $98^{\circ} \mathrm{C}$ for $10 \mathrm{~s}$, annealing at $53^{\circ} \mathrm{C}$ for $30 \mathrm{~s}$ and extending at $68^{\circ} \mathrm{C}$ for $60 \mathrm{~s}$ per kb; final extending step at $68^{\circ} \mathrm{C}$ for $12 \mathrm{~min}$. In addition, two standard PCR reactions were performed (Supplementary material 1). One used the rrnL gene universal primers (Palumbi et al., 1991) to close the gap between long PCR rrnL primers, and the other used coxlgene universal primers (Folmer et al., 1994) to amplify a fragment, which after Sanger sequencing at the MNHN was used to check that final assemblies corresponded to the correct species. The standard PCR reactions contained $2.5 \mu \mathrm{l}$ of $10 \mathrm{x}$ buffer, $1.5 \mu \mathrm{l}$ of $\mathrm{MgCL}_{2}(25 \mathrm{mM}), 0.5 \mu \mathrm{l}$ of dNTPs $(2.5 \mathrm{mM}$ each), $0.5 \mu \mathrm{l}$ of each primer $(10 \mathrm{mM}), 0.5-1 \mu \mathrm{l}(10-40 \mathrm{ng} / \mu \mathrm{l})$ of template DNA, $0.2 \mu \mathrm{l}$ of Taq DNA polymerase 5PRIME (Hamburg, Germany), and sterilized distilled water up to $25 \mu \mathrm{l}$. The following program was applied: initial denaturing step at $94^{\circ} \mathrm{C}$ for $60 \mathrm{~s} ; 45$ cycles of denaturalization at $94^{\circ} \mathrm{C}$ for $30 \mathrm{~s}$, annealing at $44^{\circ} \mathrm{C}$ for $60 \mathrm{~s}$ and extending at $72^{\circ} \mathrm{C}$ for $90 \mathrm{~s}$; final extending step at $72^{\circ} \mathrm{C}$ for $5 \mathrm{~m}$.

Long-PCR products were purified by ethanol precipitation. Amplified fragments 
from the same mt genome were pooled together in equimolar concentrations and subjected to massive parallel sequencing. For each conoidean mt genome a separate indexed library was constructed using the NEXTERA XT DNA library prep Kit (Illumina, San Diego, CA, USA) at AllGenetics (A Coruña, Spain). Each of the libraries contained in addition $\mathrm{mt}$ genomes of unrelated animals (e.g., snakes, spiders) from different projects. The indexed libraries were run in a single lane in an Illumina HiSeq2000 (100 Pair-ended) at Macrogen (Seoul, Korea).

\subsection{Genome assembly and annotation}

Reads were sorted according to their indexes, and the assembly of the different $\mathrm{mt}$ genomes was performed in the TRUFA webserver (Kornobis et al., 2015). Briefly, adapters were removed using SeqPrep (StJohn, 2011), quality of the reads was checked using FastQC v.0.10.1 (Andrews, 2010), and raw sequences were trimmed and filtered out according to their quality scores using PRINSEQ v.0.20.3 (Schmieder and Edwards, 2011). Filtered reads were used for de novo assembly of each mt genome using TRUFA default settings (minimum contig length; 200; sequence identity threshold: 0.95) only retaining contigs with a minimum length of $3 \mathrm{~kb}$. These contigs were finally overlapped in Sequencher 5.0.1 to render the different complete or nearly complete mt genomes included within each index (the one belonging to a conoidean species and those belonging to a snake or a spider). In order to estimate mean coverage, each assembled conoidean mt genome was used as reference to map the original (raw) reads with a minimum identity of $100 \%$ using Geneious ${ }^{\circledR}$ 8.0.3.

The newly determined $\mathrm{mt}$ genomes were annotated using Geneious ${ }^{\circledR} 8.0 .3$ by setting a limit of nucleotide identity of $75 \%$ to previously reported conoidean $\mathrm{mt}$ genomes (i.e., C. textile, C. borgesi, $C$. consors, F. similis, $X$. cerithiformis, and $O$. 
dimidiata). Annotations of the $13 \mathrm{mt}$ protein-coding genes were corroborated manually identifying the corresponding open reading frames using the invertebrate mitochondrial code. The transfer RNA (tRNA) genes were further identified with tRNAscan-SE 1.21 (Schattner et al., 2005), which infer cloverleaf secondary structures (with a few exceptions that were determined manually). The ribosomal RNA (rRNA) genes were identified by sequence comparison with previously reported conoidean mt genomes, and assumed to extend to the boundaries of adjacent genes (Boore et al., 2005). GenBank accession numbers of each mt genome are provided in Table 1.

\subsection{Sequence alignment}

The newly sequenced complete or nearly complete mt genomes were aligned with all orthologous conoidean mt genomes available in NCBI (Table 1). Two sequence data sets were constructed and analyzed: the first data set (hereafter referred to as the Conidae data set) was aimed to test the monophyly of Conidae and included main lineages within the family as well as closely related conoidean families. Three species of less related conoideans were selected as outgroup taxa following Puillandre et al., (2011): F. similaris (Clavatulidae); X. cerithiformis (Turridae), and O. dimidiata (Terebridae). This data set included the deduced amino acid sequences of the $13 \mathrm{mt}$ protein coding genes and the nucleotide sequences of the two rRNA genes. The second data set (hereafter referred to as the Conus data set) was aimed to test the internal phylogenetic relationships of Conus. This data set included newly determined and previously published Conus species and it was rooted with Conasprella wakayamaensis and Californiconus californicus. The data set included $13 \mathrm{mt}$ protein-coding genes and two rRNA genes, both analyzed at the nucleotide level. Phylogenetic analyses of the protein-coding genes at the amino acid and nucleotide levels in the Conidae and Conus 
data sets, respectively, was aimed at maximizing phylogenetic information (by selecting the appropriate levels of sequence variation) as each data set was addressing different taxonomic questions (see discussion). In order to construct these two data sets, the deduced amino acid sequences of the $13 \mathrm{mt}$ protein-coding genes were aligned separately and used to guide the alignment of the corresponding nucleotide sequences with Translator X (Abascal et al., 2010). Nucleotide sequences of the mt rRNA genes were aligned separately using MAFFT v7 (Katoh and Standley, 2013) with default parameters. Ambiguously aligned positions were removed using Gblocks, v.0.91b (Castresana, 2000) with the following settings: minimum sequence for flanking positions: $85 \%$; maximum contiguous non-conserved positions: 8 ; minimum block length: 10; gaps in final blocks: no. Finally, the different single alignments were concatenated into the two data matrices using Geneious ${ }^{\circledR}$ 8.0.3.

\subsection{Phylogenetic analyses}

Phylogenetic relationships of family Conidae and genus Conus were inferred using maximum likelihood (ML; Felsenstein, 1981) and Bayesian inference (BI; Huelsenbeck and Ronquist, 2001). ML analyses were conducted with RAxML v7.3.1 (Stamatakis, 2006) using the rapid hill-climbing algorithm and 10,000 bootstrap pseudoreplicates (BP). BI analyses were conducted using MrBayes v3.1.2 (Ronquist and Huelsenbeck, 2003), running four simultaneous Markov chains for 10 million generations, sampling every 1000 generations, and discarding the first $25 \%$ generations as burn-in (as judged by plots of ML scores and low SD of split frequencies) to prevent sampling before reaching stationarity. Two independent Bayesian inference runs were performed to increase the chance of adequate mixing of the Markov chains and to increase the chance of detecting failure to converge, as determined using Tracer v1.6 (Rambaut and 
Drummond, 2007). Node support was assessed based on Bayesian Posterior Probabilities (BPP).

The best partition schemes and best-fit models of substitution for the two data sets were identified using Partition Finder and Partition Finder Protein (Lanfear et al., 2012) with the Bayesian Information Criterion (BIC; Schwarz, 1978). For the protein-coding genes of the Conidae data set (analyzed at the amino acid level) the partitions tested were: all genes grouped; all genes separated (except nad4/4L and atp6/8); genes grouped by enzymatic complexes ( $n a d, c o x$, atp, cob; see Supplementary Material 2 for selected best fit partitions and models). For the protein-coding genes of the Conus data set, which were analyzed at the nucleotide level, the partitions tested were: all genes grouped; all genes separated (except nad4/ 4L and atp6/8); genes grouped by subunits (see Supplementary Material 2). In addition, these three partitions schemes were tested taking into account separately the three codon positions). The rRNA genes (analyzed at the nucleotide level) in both data sets were tested separately with two different schemes, as genes separated or combined.

\subsection{Estimation of divergence times}

The program BEAST v.1.7 (Drummond and Rambaut, 2007) was used to perform a Bayesian estimation of divergence times among major conoidean lineages based on the mt amino acid data set. An uncorrelated relaxed molecular clock was used to infer branch lengths and nodal ages. The tree topology was set based on a combination of the Conidae and Conus trees. For the clock model, the lognormal relaxed-clock model was selected, which allows rates to vary among branches without any a priori assumption of autocorrelation between adjacent branches. For the tree prior, a Yule process of speciation was employed. The partitions selected by Partition Finder Protein (see above) were applied. The final Markov chain was run twice for 100 million generations, 
sampling every 10,000 generations and the first 10 million was discarded as part of the burn-in process, according to the convergence of chains checked with Tracer v.1.5. (Rambaut and Drummond, 2007). The effective sample size of all the parameters was above 200 .

The posterior distribution of the estimated divergence times was obtained by specifying two calibration points as priors for divergence times of the corresponding splits. Fossils provided hard minimum bounds (offset) and mean and standard deviations were chosen so that the $95 \%$ probability limit corresponds to a soft maximum bound. For the divergence of Conidae, a calibration point was set at a minimum of 55 million years ago (Mya) with a 95\% upper limit of 58.1 MYA (lognormal distribution, offset: 55; mean: 1; standard deviation: 1) based on the oldest known fossils of Hemiconus rouaulti (France) and Hemiconus concinnus (England) that likely belong to the stem group of the family Conidae (Tucker and Tenorio, 2009) and were documented from the Lower Eocene (Kohn, 1990). A second calibration point was set at the divergence time between $C$. ventricosus and C. borgesi. Fossils of $C$. (Lautoconus) ventricosus become recognized in the Middle-Lower Miocene (16.4 to 20.5 Mya) of Cuenca de Piemonte (Italy) (Sacco, 1893). This interval coincides with the inferred origin of Cape Verde cone snails and the age of the archipelago (Cunha et al., 2005). Therefore, a normal distribution (recommended for inferred a secondary calibrations and biogeographical datings; Ho and Phillips, 2009) was applied. The 95\% upper and lower limits were set to 21 and 16 MYA, respectively (mean: 18.5; standard deviation: $1.5)$.

\section{Results}

\subsection{Sequencing and assembly}


Within Conidae, the mt genomes of $C$. californicus, Conus (Kalloconus) venulatus, and C. ventricosus were determined complete whereas those of Conus (Lautoconus) hybridus, Conus (Eugeniconus) nobilis (subspecies victor), C. wakayamaensis, Lilliconus sagei, Profundiconus teramachii, and Pseudolilliconus traillii lacked the control region because it could not be amplified. In addition, the nearly complete (without control region) mt genomes of Benthomangelia sp. (Mangeliidae), Tomopleura sp. (Borsoniidae), and Glyphostoma sp. (Clathurellidae) were also amplified and sequenced. The number of reads, mean coverage, and length of each mt genome are provided in Table 1. The mt genomes of $C$. californicus and $C$. ventricosus received the minimum $(15,542)$ and maximum $(249,121)$ reads, respectively. The minimum $(119 x)$ and maximum $(1,619 \mathrm{x})$ coverage corresponded to Benthomangelia sp. and $C$. ventricosus, respectively.

\subsection{Structural features and mitochondrial organization}

The newly determined mt genomes had the usual 13 protein coding, 2 rRNA, and 22 tRNA genes reported in other animal mt genomes (see annotation and main features of each of these mt genomes in Supplementary Material 3). In few instances, the control region between $\operatorname{trnF}$ and $\operatorname{cox} 3$ genes was also amplified allowing the completion of the $\mathrm{mt}$ genome. All but two of the analyzed conoidean mt genomes conformed to the consensus genome organization described for Caenogastropoda (Osca et al., 2015) with most genes encoded by the major strand and only a cluster of tRNA genes (MYCWQGE) and the $\operatorname{trnT}$ gene encoded by the minor strand (Fig. 1). The only exceptions were the mt genome of L. sagei, which showed the translocation of the $\operatorname{trn} L$ (uag) and $\operatorname{trn} L$ (uaa) genes and the inversion and translocation of the $\operatorname{trn} T$ gene, as well as the mt genomes of P. traillii and Tomopleura sp., which showed the 
translocation of the $\operatorname{trn} T$ gene (Fig.1). In addition, we were not able to find the $\operatorname{trnR}$ gene of the mt genome of $L$. sagei in its usual position (within the cluster KARNI), but we cannot discard that it might have been translocated near to the control region, which could not be amplified in this mt genome (Fig. 1).

\subsection{Phylogenetic relationships of Conidae}

The molecular phylogeny of Conidae was reconstructed based on the Conidae data set using probabilistic methods (Fig. 2). The final matrix was 5870 positions long. Both, $\operatorname{ML}(-\operatorname{lnL}=57997.47)$ and $\mathrm{BI}(-\operatorname{lnL}=59051.42$ for run1; $-\operatorname{lnL}=59051.06$ for run2) arrived at almost identical topologies (Fig. 2) only differing in the internal relationships within Conus. The reconstructed phylogeny recovered Borsoniidae + Clathurellidae as sister group to Mangeliidae + Conidae, although both groupings received moderate and low statistical support, respectively (Fig. 2). The monophyly of Conidae received strong statistical support (1 BPP, 90\% BP; Fig. 2). Within Conidae, Profundiconus was recovered as sister group of the remaining members of the family. Within the latter, a clade including Californiconus and Lilliconus + Pseudolilliconus was the sister group of Conasprella to the exclusion of Conus (Fig. 2). All recovered phylogenetic relationships within Conidae received strong support (Fig. 2) except those within Conus.

\subsection{Phylogenetic relationships of Conus}

In order to further determine phylogenetic relationships within the genus Conus, a second alignment named Conus data set was analyzed with probabilistic methods (Fig. 3). The final matrix was 13473 positions long. Both ML $(-\operatorname{lnL}=69568.03)$ and BI $(-\operatorname{lnL}$ $=69594.80$ for run $1 ;-\operatorname{lnL}=69592.68$ for run2) arrived at fully resolved phylogenetic trees with all nodes strongly supported (above 70\% BP and 0.99 BPP; Fig. 3). Among 
Conus studied species, C. tribblei was recovered as sister group of the remaining, which were organized into two sister clades. One clade included C. consors $+C$. tulipa as sister group of $C$. textile $+C$. nobilis. The other clade included $C$. venulatus as sister group of a clade including C. hybridus and C. ventricosus + C. borgesi (Fig. 3).

\subsection{Divergence times}

Major cladogenetic events within Conoidea were dated using an uncorrelated relaxed molecular clock model, which was calibrated with several European fossils belonging to the stem and crown groups of Conidae. The origin of the conoidean families closely related to Conidae is dated at a mean of 67 (84-57, credible intervals) Mya, quite close in geological times to the origin of the family Conidae itself about 59 (73-55) Mya (Fig. 4). The branching of Profundiconus is estimated to have occurred around 56 (70-49) Mya and the split between the lineage leading to extant Conus and the clade containing Californicus, Conasprella, Lilliconus, and Pseudolilliconus was dated at 51 (64-44) Mya (Fig. 4). Divergence among these latter four genera occurred successively between 46-30 (59-22) Mya. The radiation of the analyzed Conus species was estimated to have occurred between 24-15 (30-12) Mya (Fig. 4).

\section{Discussion}

Thanks to the combination of long PCR and massive sequencing techniques, we were able to add in the present work up to12 new mt genomes to the catalogue of conoidean $\mathrm{mt}$ genomes. Not only we more than double the number of available $\mathrm{mt}$ genomes for this superfamily of Caenogastropoda, but also we provide a better representation of the diversity of the superfamily by adding the first representatives of five genera within Conidae and three closely related families. Both, number of reads per mt genome and 
final coverage were high, with a direct relationship between both parameters except in the case of the mt genomes of Californiconus and Pseudolilliconus, which showed higher coverage than expected. The presence of reads with the same index and in the same lane corresponding to distantly related animal species did not interfere in the correct assembly of each conoidean mt genome as assessed by empirical PCR amplification and sequencing of the coxl gene of each analyzed species. We were able to complete only three out of the $12 \mathrm{mt}$ genomes. Completed $\mathrm{mt}$ genomes showed short control regions and interestingly, the coverage in these regions was much lower than average (despite being part of a longer PCR fragment in equimolar concentration). It is likely that longer and more complex (with secondary structures) control regions in the remaining mt genomes prevented Taq polymerase for completing the PCR reactions in some species. In those cases, outward primers were designed in the $\operatorname{trn} F$ and $\operatorname{cox} 3$ genes at the boundaries of the control region (see Supplementary Material 1).

\subsection{Gene order evolution}

The mt genomes of mollusks, and of gastropods in particular, are known for having relatively high rates of gene rearrangement (Grande et al., 2008; Stöger and Schrödl, 2013). Major changes in mt genome organization including translocations and inversions of protein coding and/or rRNA genes normally occur between main lineages of gastropods (e.g., Patellogastropoda or Heterobranchia versus other gastropod lineages; Grande et al., 2008) or in particular groups within main lineages (e.g., superfamily Vermetoidea witihin Caenogastropoda; Rawlings et al., 2010). Interestingly, these high rates of rearrangement are normally associated with high mutational rates, leading to long branches in phylogenetic trees (Stöger and Schrödl, 2013; Osca et al., 2015; Uribe et al., 2016). Nevertheless, for the majority of groups and species within a 
main gastropod lineage, gene order is relatively stable and rearrangements are restricted to tRNA genes, if any (Grande et al., 2008). Hence, it is possible to reconstruct a consensus gene order for the hypothetical ancestor of the different main gastropod lineages (Grande et al., 2008; Stöger and Schrödl, 2013; Osca et al., 2014; Osca et al., 2015; Uribe et al., 2016). The gene order of the $12 \mathrm{mt}$ genomes here sequenced generally conforms to the consensus genome organization for Caenogastropoda and is identical to the one inferred for Neogastropoda (Cunha et al., 2009; Osca et al., 2015). Among previously published conoidean mt genomes, it was reported the translocation of the trnV and trnS in $O$. dimidiata and F. similis, respectively (Cunha et al., 2009). Here, the Tomopleura sp. mt genome shows a translocation of the trnT, which is normally found next to the $\operatorname{trn} S$ (uga) gene and encoded by the minor strand, to a location between the coxl and cox 2 genes. The rearrangement of this tRNA gene is relatively frequent among caenogastropods (Osca et al., 2015) and occupies the same position in $P$. traillii. In addition, the mt genome of L. sagei presents a translocation and inversion of the trnT gene, which is found next to the $r r n L$ gene and encoded by the major strand, in a position were normally the $\operatorname{trn} L$ (uag) and $\operatorname{trn} L$ (uaa) genes are found. In this mt genome, however, the two trnL genes have moved next to the cox2 gene. Interestingly, both events seem to be connected because at the same position where the $\operatorname{trn} T$ is found, the minor strand could putatively encode for a $\operatorname{trnL}$ (uaa) gene (see Supplementary Material 4), indicating that the trnT and the reverse complementary trnL (uaa) gene sequences are very similar. Moreover, between the two trnL genes there is space for the coding of a $\operatorname{trn} T$ gene in the major strand (see Supplementary Material 4), which could be the remnant of an ancient duplication. In addition, we were not able to detect the $\operatorname{trn} R$ gene, in the otherwise highly conserved KARNI cluster. This missing gene might have moved next to the control region, which could not be sequenced. 
Finally, it is worth mentioning that in many gastropod $\mathrm{mt}$ genomes high rates of rearrangement and of substitution rates are normally correlated (Rawlings et al., 2010; Stöger and Schrödl, 2013; Osca et al., 2014; Osca et al., 2015). However, here this correlation does not hold. The mt genomes of Tomopleura and Pseudolliliconus have the same gene order, but only the latter genus has a very long branch in the phylogenetic tree, much longer than that of Lilliconus, whose mt genome has more rearrangements than any other (and even in this case only associated to minor tRNA gene rearrangements).

\subsection{Phylogenetic relationships of Conidae}

The hyperdiverse superfamily Conoidea has been the subject of recent molecular phylogenetic studies (Puillandre et al., 2008; Puillandre et al., 2011; Puillandre et al., 2014a) that supported some morphology-based classifications (Taylor et al., 1993) and allowed discerning the closest families to Conidae, i.e., Conorbidae, Raphitomidae, Mangeliidae, Borsoniidae, Clathurellidae, and Mitromorphidae. These molecular phylogenies were based on the concatenation of partial mt genes and were unable to resolve phylogenetic relationships among these families, and thus determining the sister group of Conidae. A clade including Conorbidae and Borsoniidae was tentatively recovered as sister group of Conidae but without statistical support (Puillandre et al., 2011). In the phylogeny here reconstructed based on complete mt genomes, the Mangeliidae were recovered as sister group of Conidae but this relationship showed low statistical support impeding the resolution of this long-standing question. Here, we added a considerable amount of sequence data (mt genomes) in trying to gain further resolution in this part of the Conoidea tree but without success. However, our data set was biased towards representatives of the family Conidae. Hence, in future studies, it 
would be important to increase taxon representation within closely related families, as well as include missing important families such as Conorbidae, Raphitomidae, and Mitromorphidae. Moreover, the possibility nowadays of obtaining a considerable number of nuclear loci using next-generation sequencing techniques opens a potent approach to increase phylogenetic resolution. In any case, it is clear from the reconstructed phylogenetic trees that the lengths of internal nodes connecting these families are rather short, which may indicate and ancient radiation, and therefore that achieving high statistical support and final resolution of these phylogenetic relationships will be challenging.

The monophyly of the family Conidae was highly supported in the reconstructed phylogeny, as were relationships among its main deep lineages. In this case, we had a complete representation of main lineages and even new ones, allowing us to reach stronger conclusions. The genus Profundiconus was recovered as sister group to the remaining members of Conidae in agreement with previous molecular phylogenies (Puillandre et al., 2011; Puillandre et al., 2014a) but here showing high statistical support. Phylogenetic relationships among the remaining Conidae differed with respect to previous studies. Here, Conus was recovered as the sister group of a clade containing Conasprella as sister group of Californiconus and Lilliconus + Pseudolilliconus. In previous molecular phylogenies (Puillandre et al., 2011; Puillandre et al., 2014a), Californiconus was recovered as sister group of Conasprella + Conus, with low BP support (50-63 \%) in ML and relatively high BPP support in BI (0.96-0.98). The differences between the present study and previous ones are the increased number of analyzed positions, the use of amino acids, which show a better phylogenetic information/ noise ratio at deeper nodes due to lower saturation levels, and the inclusion of new lineages of Conidae that proved to be highly divergent. Interestingly, a close 
relationship between Californiconus and Conasprella (Lilliconus and Pseudolilliconus were not included in the study) was already suggested by Tucker and Tenorio (2009). The reconstructed phylogeny is statistically robust within Conidae and serves as a framework for studying evolutionary processes associated with the diversification of the family. All members of Conidae are presumed vermivorous except $C$. californicus, which has a wide diet based on worms, mollusks, crustaceans and fishes (Biggs et al., 2010), and certain derived groups of Conus that feed on fishes or mollusks. The strongly supported phylogenetic position of $C$. californicus deeply nested within the Conidae tree reinforces the hypothesis that the ancestor of Conidae was a hunter of polychaete worms (Puillandre et al., 2014a). The 16 extant species belonging to Profundiconus live in the deep sea in the Indo-Pacific region (Tenorio and Castelin, 2016). The relative phylogenetic position of this genus within the family Conidae suggests that the group represents an early offshoot that has survived since the middle Eocene.

\subsection{Phylogenetic relationships of Conus}

The reconstructed phylogeny based on the Conidae data set lacked resolution within Conus. This was likely due to low levels of variation in the amino acids at this hierarchical taxonomic level. In order to maximize phylogenetic information, a second data set was constructed with protein coding genes analyzed at the nucleotide level. The Conus data set rendered a fully resolved phylogeny with high statistical support in all nodes. The reconstructed phylogenetic relationships are fully congruent with those recovered in a previous molecular phylogeny with an extended taxon sampling (Puillandre et al., 2014a). The presumed vermivorous species $C$. tribblei from the West Pacific and Indian Oceans was recovered as sister group of the remaining taxa. Within this, two main groups were recovered, corresponding to Indo-Pacific and Western 
Atlantic- Mediterranean species, respectively. Within the Indo-Pacific clade, two species, C. consors and C. tulipa, feeding on fish clustered together as sister group of two species, $C$. textile and $C$. nobilis, feeding on mollusks (Tucker and Tenorio, 2009; Puillandre et al., 2014a). All species in the Western Atlantic- Mediterranean clade are worm hunters. Obviously, the present phylogenetic tree has only a minor representation of the species diversity of the genus (nine out of 800 species) and is biased in terms of taxonomy (three of the species belong to the same subgenus), distribution (half of the species are from the Atlantic Ocean), and life history traits (about half of the species are fish- or mollusk-hunters) when compared with the genus as a whole. Therefore, we limited our interpretation of the results to character states at the tips of the tree and refrained from performing proper ancestral character-state reconstructions, which would be meaningless at this moment. Nevertheless, the present work emphasizes that complete mt genomes are a very promising tool for achieving important levels of resolution within Conus, and that a more complete data set will certainly help a better understanding of the evolutionary processes (diet and conotoxin evolution, biogeography) that led to the extraordinary diversity encompassed by the genus.

\subsection{Divergence times and taxonomic levels within family Conidae}

The reconstructed time tree using a relaxed molecular clock model dated the origin of the family Conidae in the Paleocene, shortly after the Cretaceous-Tertiary boundary (about 59 Mya, at the Danian/ Selanian transition), which is right before the earliest fossils of cone snails are documented. According to the chronogram, the first burst of cladogenetic events within the family Conidae occurred successively during the Paleocene and Eocene and corresponded to the origin of the major lineages (genera) in parallel to the appearance of closely related conoidean families (Fig. 4; Kohn, 1990). 
The fossil record would suggest that some of these conoidean families may have appeared before (Powell, 1942), but this would need to be confirmed with a full revision of the different reported fossils and confirmation of their ascriptions to the different families. The diversity of Conidae increased steadily during the Oligocene until a major radiation in the Indo-Pacific region occurred in the Miocene corresponding to the appearance of subgenera within Conus (Fig. 4; Kohn, 1990). However, the analyzed Conus species correspond to clades that appeared relatively late during the evolution of the genus (Puillandre et al., 2014a): the inclusion of species belonging to the subgenera Fraterconus, Stephanoconus, Strategoconus, Klemaeconus, and Turriconus, which supposedly diverged before (Puillandre et al., 2014a), will likely push back our estimates for the original radiation of Conus. Given our taxon sampling we could not date the most recent radiation in the family corresponding to the appearance of extant species in the Pleistocene (Kohn, 1990; the magnitude of this radiation, >800 living species versus 100-150 fossils species at the maximum diversity 10 Mya, directly depends on how complete and unbiased is the fossil record). Another important radiation of Conus occurred locally during the middle-lower Miocene in the Cape Verde archipelago shortly after the emergence of these volcanic islands (Cunha et al., 2005).

In an ultrametric tree, the distances from the root to every branch tip are equal, the length of the branches is proportional to the time of divergence, and hence, branch length of the different lineages can be roughly compared in order to provide a criterion for taxonomic level delimitation above species (Johns and Avise, 1998). The hierarchical level of the main clades within Conidae has been an important source of conflict between morphological- (Tucker and Tenorio, 2009) and molecular-based (Puillandre et al., 2014b) classifications. By comparing the branch lengths of the different accepted families within Conoidea (Puillandre et al., 2011), it seems that 
earlier lineages within Conidae could have appeared before some other related families of Conoidea. However, the fossil record suggests that some families of "turrids" (i.e., Conoidea except Conidae and Terebridae) likely appeared before the cone snails (Powell, 1942). Furthermore, while cone snails are represented by multiple lineages, and several species within Conus, in our phylogenetic analyses, the closely related families are represented by only one species each, and even some families, also suggested as closely related to cone snails (Puillandre et al. 2011), e.g., Clathurellidae, Mitromorphidae, Raphitomidae, are absent. Therefore, more data, and in particular a better coverage of the Conoidea diversity, together with calibration points for non-conesnails Conoidea, are needed to provide a time-calibrated phylogeny that could be used to discuss taxonomic ranks.

\section{Conclusions}

The ancient radiation at the origin of conoidean families combined with the extraordinary species diversity within Conidae have hindered past attempts of resolving the phylogeny of the family based on concatenated partial mt genes. Here, up to 12 complete or nearly complete (without control region) $\mathrm{mt}$ genomes of all main lineages of Conidae and certain selected closely related conoidean families were sequenced and used for phylogenetic analyses. The monophyly of the family including genus Profundiconus was recovered with high support, and high resolution of phylogenetic relationships was achieved not only among all genera, but also among an abridged representation of species within the most diverse genus (Conus). Our results indicate that complete mt genomes are a very promising phylogenetic tool to reconstruct a statistically robust phylogeny of the family. This approach could be complemented with the development (using next generation sequencing techniques) of nuclear markers, 
which could be particularly useful for resolving deeper phylogenetic relationships i.e., those among conoidean families. Altogether, these robust molecular phylogenies would allow setting the needed framework to further our understanding of the evolutionary processes that generated and maintain the remarkable taxonomic and ecological diversity of cone snails.

\section{Acknowledgements}

The MNHN Indo-Pacific material originates from a series of expeditions and workshops, conducted in the context of the "Our Planet Reviewed" programme with Pro-Natura International (ATIMO VATAE to South Madagascar in partnership with Université de Tuléar; PAPUA NIUGINI 2012 and KAVIENG 2014 to Papua New Guinea, in partnership with University of Papua New Guinea and the National Fisheries College). The organizers thank the Total Foundation, Prince Albert II of Monaco Foundation, Stavros Niarchos Foundation, Fondation EDF, Vinci Entrepose Contracting and Richard Lounsbery Foundation for their support to these expeditions. We are indebted to José Utge, Agnès Dettaï and Laetitia Aznar (MNHN, Paris), and Ana Echeverry (MNCN) for technical assistance in the laboratory. Several specimens of $C$. californicus were kindly donated by Rick Negus. We are grateful to Jesús Marco and Luis Cabellos who provided access to the supercomputer Altamira at the Institute of Physics of Cantabria (IFCA-CSIC), member of the Spanish Supercomputing Network, for performing phylogenetic analyses. This work was supported by the Spanish Ministry of Science and Innovation (CGL2010-18216 and CGL2013-45211-C2-2-P to RZ; BES2011-051469 to JEU), by the "Service de Systématique Moléculaire” (UMS 2700 CNRS-MNHN), by the ATM (“Action transversal du Muséum”) Emergences of the MNHN and by the project CONOTAX, funded by the French Agence Nationale de la 
Recherche (ANR-13-JSV7-0013-01 to NP). Access of JEU to the MNHN collections and facilities was funded by the EU Synthesys Project. 


\section{References}

Abascal, F., Zardoya, R., Telford, M.J., 2010. TranslatorX: multiple alignment of nucleotide sequences guided by amino acid translations. Nucleic Acids Res. 38, W7-13.

Andrews, S., 2010. FastQC. http://www.bioinformatics.babraham.ac.uk/projects/fastqc/.

Bandyopadhyay, P.K., Stevenson, B.J., Cady, M.T., Olivera, B.M., Wolstenholme, D.R., 2006. Complete mitochondrial DNA sequence of a Conoidean gastropod, Lophiotoma (Xenuroturris) cerithiformis: Gene order and gastropod phylogeny. Toxicon 48, 29-43.

Bandyopadhyay, P.K., Stevenson, B.J., Ownby, J.-P., Cady, M.T., Watkins, M., Olivera, B.M., 2008. The mitochondrial genome of Conus textile, coxI-coxII intergenic sequences and Conoidean evolution. Mol. Phylogenet. Evol. 46, 215-223.

Barghi, N., Concepcion, G.P., Olivera, B.M., Lluisma, A.O., 2015. Characterization of the complete mitochondrial genome of Conus tribblei Walls, 1977. Mitochondrial DNA, 1-2.

Biggs, J.S., Watkins, M., Puillandre, N., Ownby, J.-P., Lopez-Vera, E., Christensen, S., Moreno, K.J., Bernaldez, J., Licea-Navarro, A., Corneli, P.S., 2010. Evolution of Conus peptide toxins: analysis of Conus californicus Reeve, 1844. Mol. Phylogenet. Evol. 56, 1-12.

Boore, J.L., Macey, J.R., Medina, M., 2005. Sequencing and comparing whole mitochondrial genomes of animals. Methods Enzymol. 395, 311 - 348.

Bouchet, P., Kantor, Y.I., Sysoev, A., Puillandre, N., 2011. A new operational classification of the Conoidea (Gastropoda). J. Molluscan. Stud. 77, 273-308. 
Brauer, A., Kurz, A., Stockwell, T., Baden-Tillson, H., Heidler, J., Wittig, I., Kauferstein, S., Mebs, D., Stöcklin, R., Remm, M., 2012. The mitochondrial genome of the venomous cone snail Conus consors. PLoS. ONE 7, e51528.

Castresana, J., 2000. Selection of conserved blocks from multiple alignments for their use in phylogenetic analysis. Mol. Biol. Evol. 17, 540-552.

Chen, P.-W., Hsiao, S.-T., Huang, C.-W., Chen, K.-S., Tseng, C.-T., Wu, W.-L., Hwang, D.-F., 2015. The complete mitochondrial genome of Conus tulipa (Neogastropoda: Conidae). Mitochondrial DNA, 1-2.

Cotton, B.C., 1945. A catalogue of the cone snails (Conidae) in the South Australian Museum. Rec. South Aust. Mus 8, 229-280.

Cunha, R., Grande, C., Zardoya, R., 2009. Neogastropod phylogenetic relationships based on entire mitochondrial genomes. BMC Evol. Biol. 9, 210.

Cunha, R.L., Castilho, R., Rüber, L., Zardoya, R., 2005. Patterns of cladogenesis in the venomous marine gastropod genus Conus from the Cape Verde Islands. Syst. Biol $54,634-650$.

Da Motta, A.J., 1991. A systematic classification of the gastropod family Conidae at the generic level. La Conchiglia, Roma.

Drummond, A., Rambaut, A., 2007. BEAST: Bayesian evolutionary analysis by sampling trees. BMC Evol Biol 7, 214.

Duda, T.F., Kohn, A.J., 2005. Species-level phylogeography and evolutionary history of the hyperdiverse marine gastropod genus Conus. Mol. Phylogenet. Evol. 34, 257272.

Duda, T.F., Kohn, A.J., Palumbi, S.R., 2001. Origins of diverse feeding ecologies within Conus, a genus of venomous marine gastropods. Biol. J. Linn. Soc. 73, 391-409. 
Duda, T.F., Rolan, E., 2005. Explosive radiation of Cape Verde Conus, a marine species flock. Mol. Ecol. 14, 267-272.

Dutertre, S., Jin, A.-H., Vetter, I., Hamilton, B., Sunagar, K., Lavergne, V., Dutertre, V., Fry, B.G., Antunes, A., Venter, D.J., Alewood, P.F., Lewis, R.J., 2014. Evolution of separate predation- and defence-evoked venoms in carnivorous cone snails. Nat. Comm. 5, 3521 .

Espiritu, D.J.D., Watkins, M., Dia-Monje, V., Cartier, G.E., Cruz, L.J., Olivera, B.M., 2001. Venomous cone snails: molecular phylogeny and the generation of toxin diversity. Toxicon 39, 1899-1916.

Felsenstein, J., 1981. Evolutionary trees from DNA sequences: A maximum likelihood approach. J. Mol. Evol. 17, 368-376.

Folmer, O., Black, M., Hoeh, W., Lutz, R., Vrijenhoek, R., 1994. DNA primers for amplification of mitochondrial cytochrome $c$ oxidase subunit I from diverse metazoan invertebrates. Mol. Mar. Biol. Biotechnol. 3, 294-299.

Grande, C., Templado, J., Zardoya, R., 2008. Evolution of gastropod mitochondrial genome arrangements. BMC Evol. Biol. 8, 61.

Ho, S.Y.W., Phillips, M.J., 2009. Accounting for calibration uncertainty in phylogenetic estimation of evolutionary divergence times. Syst. Biol 58, 367-380.

Holford, M., Zhang, M.-M., Gowd, K.H., Azam, L., Green, B.R., Watkins, M., Ownby, J.-P., Yoshikami, D., Bulaj, G., Olivera, B.M., 2009. Pruning nature: Biodiversityderived discovery of novel sodium channel blocking conotoxins from Conus bullatus. Toxicon 53, 90-98.

Huelsenbeck, J., Ronquist, F., 2001. MrBayes: Bayesian inference of phylogenetic trees. Bioinformatics 17, 754-755. 
Johns, G.C., Avise, J.C., 1998. A comparative summary of genetic distances in the vertebrates from the mitochondrial cytochrome $b$ gene. Mol. Biol. Evol. 15, 14811490.

Katoh, K., Standley, D.M., 2013. MAFFT Multiple sequence alignment software version 7: improvements in performance and usability. Mol. Biol. Evol. 30, 772780.

Kohn, A.J., 1959. The Ecology of Conus in Hawaii. Ecol. Monogr. 29, 47-90.

Kohn, A.J., 1990. Tempo and mode of evolution in Conidae. Malacologia 32, 55-67.

Kornobis, E., Cabellos, L., Aguilar, F., Frías-López, C., Rozas, J., Marco, J., Zardoya, R., 2015. TRUFA: A user-friendly web server for de novo RNA-seq analysis using cluster computing. Evol. Bioinform. 11, 97-104.

Kraus, N.J., Corneli, P.S., Watkins, M., Bandyopadhyay, P.K., Seger, J., Olivera, B.M., 2011. Against expectation: a short sequence with high signal elucidates cone snail phylogeny. Mol. Phylogenet. Evol. 58, 383-389.

Kraus, N.J., Watkins, M., Bandyopadhyay, P.K., Seger, J., Olivera, B.M., Corneli, P.S., 2012. A very short, functionally constrained sequence diagnoses cone snails in several Conasprella clades. Mol. Phylogenet. Evol. 65, 335-338.

Lanfear, R., Calcott, B., Ho, S.Y.W., Guindon, S., 2012. PartitionFinder: Combined Selection of Partitioning Schemes and Substitution Models for Phylogenetic Analyses. Mol. Biol. Evol. 29, 1695-1701.

Nam, H.H., Corneli, P.S., Watkins, M., Olivera, B., Bandyopadhyay, P., 2009. Multiple genes elucidate the evolution of venomous snail-hunting Conus species. Mol. Phylogenet. Evol. 53, 645-652.

Olivera, B.M., 2002. Conus venom peptides: reflections from the biology of clades and species. Annu. Rev. Ecol. Syst. 33, 25-47. 
Osca, D., Irisarri, I., Todt, C., Grande, C., Zardoya, R., 2014. The complete mitochondrial genome of Scutopus ventrolineatus (Mollusca: Chaetodermomorpha) supports the Aculifera hypothesis. BMC Evol. Biol. 14, 1-10.

Osca, D., Templado, J., Zardoya, R., 2015. Caenogastropod mitogenomics. Mol. Phylogenet. Evol. 93, 118-128.

Palumbi, S., Martin A, McMillan, W., Stice, L., Grabowski, G., 1991. The simple fool's guide to PCR. http://palumbi.stanford.edu/SimpleFoolsMaster.pdf, 1-45.

Powell, A.W.B., 1942. The New-Zealand Recent and Fossil Mollusca of the Family Turridae. With General Notes on Turrid Nomenclature and Systematics. Bull. Auckl. Inst. Mus. 2, 1-192.

Prashanth, J.R., Dutertre, S., Jin, A.H., Lavergne, V., Hamilton, B., Cardoso, F.C., Griffin, J., Venter, D.J., Alewood, P.F., Lewis, R.J., 2016. The role of defensive ecological interactions in the evolution of conotoxins. Mol. Ecol. 25, 598-615.

Puillandre, N., Bouchet, P., Duda Jr, T.F., Kauferstein, S., Kohn, A.J., Olivera, B.M., Watkins, M., Meyer, C., 2014a. Molecular phylogeny and evolution of the cone snails (Gastropoda, Conoidea). Mol. Phylogenet. Evol. 78, 290-303.

Puillandre, N., Duda, T.F., Meyer, C., Olivera, B.M., Bouchet, P., 2014b. One, four or 100 genera? A new classification of the cone snails. J. Molluscan. Stud.

Puillandre, N., Holford, M., 2010. The Terebridae and teretoxins: Combining phylogeny and anatomy for concerted discovery of bioactive compounds. BMC Chem. Biol. $10,1-12$.

Puillandre, N., Kantor, Y.I., Sysoev, A., Couloux, A., Meyer, C., Rawlings, T., Todd, J.A., Bouchet, P., 2011. The dragon tamed? A molecular phylogeny of the Conoidea (Gastropoda). J. Molluscan. Stud. 77, 259-272. 
Puillandre, N., Samadi, S., Boisselier, M.C., Sysoev, A.V., Kantor, Y.I., Cruaud, C., Couloux, A., Bouchet, P., 2008. Starting to unravel the toxoglossan knot: molecular phylogeny of the "turrids"(Neogastropoda: Conoidea). Mol. Phylogenet. Evol. 47, $1122-1134$

Rambaut, A., Drummond, A.J., 2007. Tracer v1.4, Available from http://beast.bio.ed.ac.uk/Tracer.

Rawlings, T., MacInnis, M., Bieler, R., Boore, J., Collins, T., 2010. Sessile snails, dynamic genomes: gene rearrangements within the mitochondrial genome of a family of caenogastropod molluscs. BMC Genomics 11, 440.

Röckel, D., Korn, W., Kohn, A.J., 1995. Manual of the Living Conidae. Vol. I, IndoPacific. Christa Hemmen Verlag, Wiesbaden.

Ronquist, F., Huelsenbeck, J.P., 2003. MrBayes 3: Bayesian phylogenetic inference under mixed models. Bioinformatics 19, 1572-1574.

Sacco, F., 1893. I molluschi dei terreni terziarii del Piemonte e della Liguria. Conidae e Conorbidae. Stamperia Reale, Torino. Italy.

Schattner, P., Brooks, A.N., Lowe, T.M., 2005. The tRNAscan-SE, snoscan and snoGPS web servers for the detection of tRNAs and snoRNAs. Nucleic Acids Res. 33, W686-W689.

Schmieder, R., Edwards, R., 2011. Quality control and preprocessing of metagenomic datasets. Bioinformatics 27, 863-864.

Schwarz, G., 1978. Estimating the Dimension of a Model. Annals of Statistics, 461-464.

StJohn, J., 2011. SeqPrep. https://github.com/jstjohn/SeqPrep.

Stöger, I., Schrödl, M., 2013. Mitogenomics does not resolve deep molluscan relationships (yet?). Mol. Phylogenet. Evol. 69, 376-392. 
Taylor, J.D., Kantor, Y.I., Sysoev, A.V., 1993. Foregut anatomy, feeding mechanisms, relationships and classification of the Conoidea (= Toxoglossa) (Gastropoda). Bull. Nat. Hist. Mus. Lond. Zool. 59, 125-170.

Tenorio, M.J., Castelin, M., 2016. Genus Profundiconus Kuroda, 1956 (Gastropoda, Conoidea): Morphological and molecular studies, with the description of five new species from the Solomon Islands and New Caledonia. Eur. J. Taxon. 173, 1-42.

Terlau, H., Olivera, B.M., 2004. Conus venoms: a rich source of novel ion channeltargeted peptides. Physiol. Rev. 84, 41-68.

Tucker, J.K., Tenorio, M.J., 2009. Systematic classification of recent and fossil conoidean gastropods: with keys to the genera of cone shells. Conchbooks.

Tucker, J.K., Tenorio, M.J., 2013. Illustrated catalog of the living cone shells. MDM Publishing, Wellington, FL, USA.

Uribe, J.E., Kano, Y., Templado, J., Zardoya, R., 2016. Mitogenomics of Vetigastropoda: insights into the evolution of pallial symmetry. Zool. Scr. 45, 145159.

Walls, J.G., 1978. Supraspecific groupings in living cones (Mollusca: Conidae). The Pariah 3, 1-13.

Watkins, M., Corneli, P.S., Hillyard, D., Olivera, B.M., 2010. Molecular phylogeny of Conus chiangi (Azuma, 1972) (Gastropods:Conidae). The Nautilus 124, 129-136.

White, T., Conrad, M., Tseng, R., Balayan, S., Golding, R., de Frias Martins, A., Dayrat, B., 2011. Ten new complete mitochondrial genomes of pulmonates (Mollusca: Gastropoda) and their impact on phylogenetic relationships. BMC Evol. Biol. 11, 295.

WoRMS, E.B., 2016. World Register of Marine Species. Available from http://www.marinespecies.org at VLIZ. Accessed 2016-05-07 


\section{Legends to Figures}

Figure 1. Mitochondrial gene orders of conoidean mitochondrial genomes. The consensus genome organization is shown as well as known exceptions. The genes encoded in the major and minor strands are shown in the top and bottom lines, respectively. Gene rearrangements (restricted to tRNA genes) are indicated by arrows. Translocated genes are in green. A gene both translocated and inverted is in blue. Striped boxes indicate regions not sequenced (note that the trnR gene is missing in L. sagei).

Figure 2. Phylogenetic relationships of Conoidea based on complete mt genomes. The reconstructed ML phylogram using Terebridae, Turridae and Clavtulidae as outgroup is shown. The family Conidae is indicated in blue. Numbers at nodes are statistical support values for ML (bootstrap proportions in percentage)/ BI (posterior probabilities). Drawings are taken from (Puillandre et al., 2014a).

Figure 3. Phylogenetic relationships within Conus based on complete mt genomes. The reconstructed ML phylogram using Californiconus and Conasprella as outgroup is shown. Numbers at nodes are statistical support values for ML (bootstrap proportions in percentage)/ BI (posterior probabilities). The distributions of the taxa (Indo-Pacific region in blue; Western Atlantic Ocean and Mediterranean in orange) and their diet are indicated.

Figure 4. Chronogram with age estimates of major divergence events among conoideans, based on the Conidae data set, and using Bayesian relaxed dating methods 
(BEAST). Horizontal bars represent $95 \%$ credibility intervals of relevant nodes, and calibration constraints are indicated with an asterisk on the corresponding nodes. Dates (and credibility intervals) are in millions of years. A geological table with periods is shown as well as species diversity of cone snails in the fossil record (modified from (Kohn, 1990) 


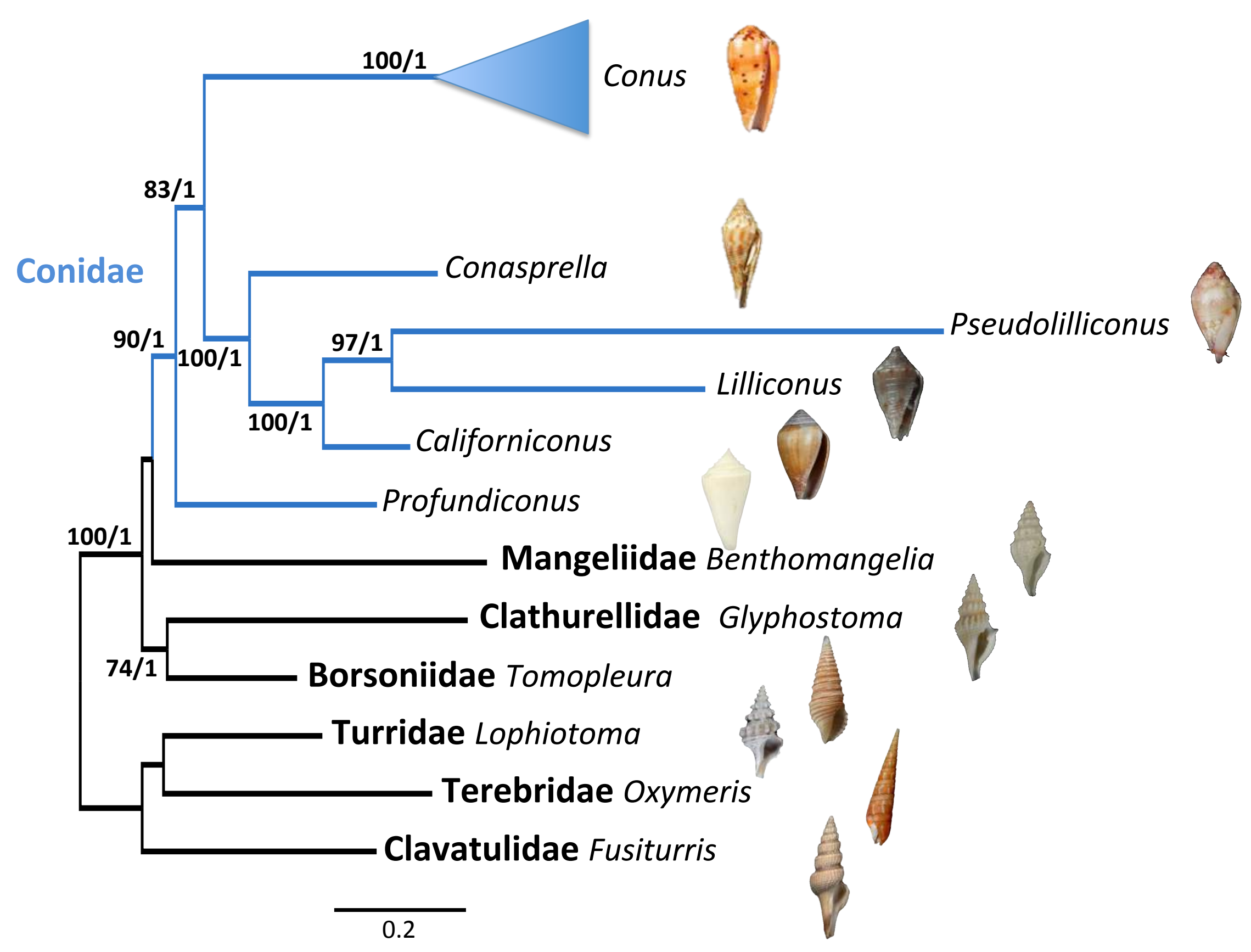




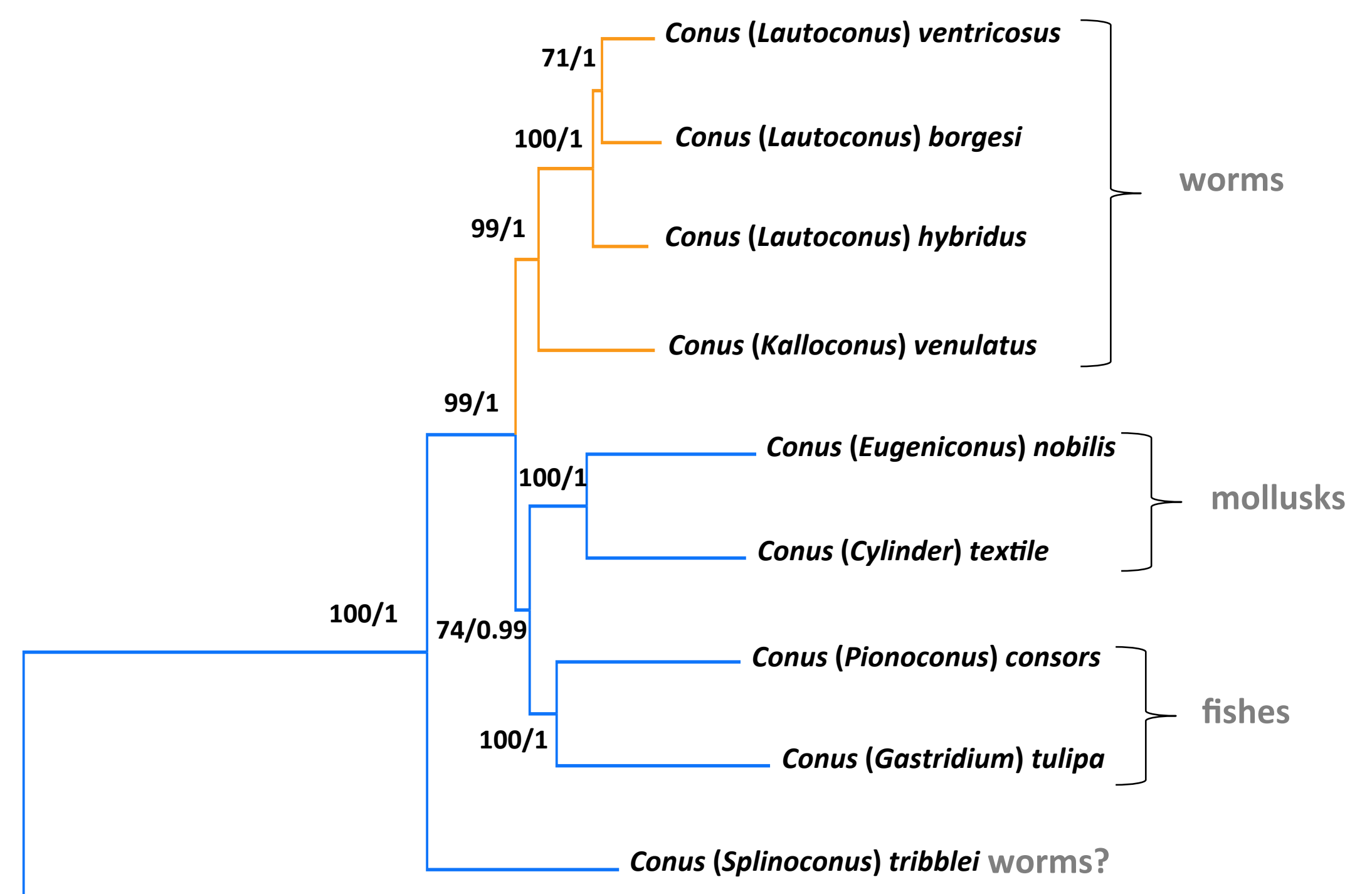

\section{Conasprella worms?}

Californiconus worms, mollusks, fishes, shrimps 

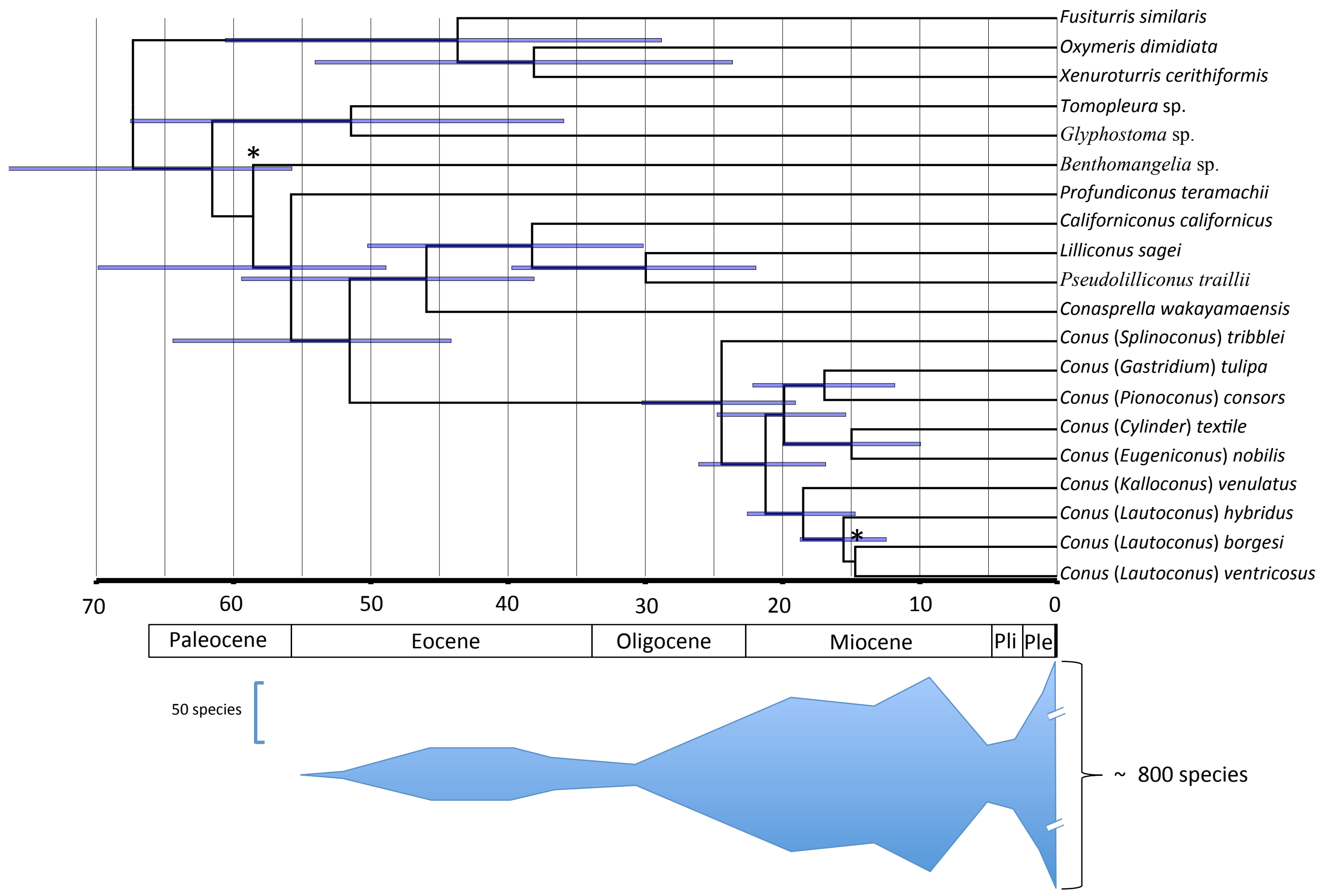
Table 1. Mitochondrial (mt) genomes analyzed in this study. Numero (\#) of reads and mean (M) coverage of each specie.

\begin{tabular}{|c|c|c|c|c|}
\hline $\begin{array}{l}\text { New mt genomes } \\
\text { Species }\end{array}$ & Family & Length (bp) & GenBank Acc. No. & Location \\
\hline Californiconus californicus* & Conidae & 15444 & KX263249 & Aqua Hedionda lagoon, Carlsbad, California, USA \\
\hline Conus (Kalloconus) venulatus* & Conidae & 15524 & KX263250 & Boavista Island, Ilheu Sal Rei, Cape Verde \\
\hline Conus (Lautoconus) ventricosus* & Conidae & 15534 & KX263251 & Faro, Portugal \\
\hline Conus (Lautoconus) hybridus & Conidae & 15276 & KX263252 & Dakar, $0-2 \mathrm{~m}, 14^{\circ} 45^{\prime} \mathrm{N} ; 17^{\circ} 32^{\prime} \mathrm{W}$ \\
\hline Conus (Eugeniconus) nobilis & Conidae & 15379 & KX263253 & Indonesia, NE Flores \\
\hline Conasprella wakayamaensis & Conidae & 15927 & KX263254 & Papua Niugini expedition (Papua New-Guinea), st. CP $4059,335 \mathrm{~m}, 02^{\circ} 38^{\prime} \mathrm{S} ; 141^{\circ} 18^{\prime} \mathrm{E}$ \\
\hline Lilliconus sagei & Conidae & 15485 & KX263255 & Atimo Vatae expedition (Madagascar), BS03, 14-18 m, 25ํ․ $26.4^{\prime} \mathrm{S} ; 44^{\circ} 56.1^{\prime} \mathrm{E}$ \\
\hline Profundiconus teramachii & Conidae & 15279 & KX263256 & Papua Niugini expedition (Papua New-Guinea), st. CP3979, $540-580 \mathrm{~m}, 04^{\circ} 44^{\prime} \mathrm{S} ; 146^{\circ} 11^{\prime} \mathrm{E}$ \\
\hline Pseudolilliconus traillii & Conidae & 14963 & KX263257 & Kavieng expedition (Papua New-Guinea), st. KB8, $13 \mathrm{~m}, 02^{\circ} 33,2^{\prime} \mathrm{S} ; 150^{\circ} 48,2^{\prime} \mathrm{E}$ \\
\hline Benthomangelia sp. & Mangeliidae & 15034 & KX263258 & Papua Niugini expedition (Papua New-Guinea), st. CP4024, $420-490 \mathrm{~m}, 05^{\circ} 22^{\prime} \mathrm{S} ; 145^{\circ} 48^{\prime} \mathrm{E}$ \\
\hline Tomopleura sp. & Borsoniidae & 15182 & KX263259 & Papua Niugini expedition (Papua New-Guinea), st. CP4023, $340-385 \mathrm{~m}, 05^{\circ} 22^{\prime} \mathrm{S} ; 145^{\circ} 48^{\prime} \mathrm{E}$ \\
\hline Glyphostoma sp. & Clathurellidae & 13370 & KX263260 & 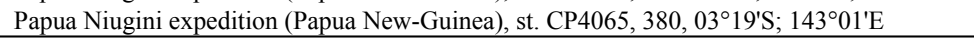 \\
\hline \multicolumn{5}{|l|}{ GenBank mt genomes } \\
\hline$\underline{\text { Species }}$ & Family & Length (bp) & GenBank Acc. No. & Reference \\
\hline Conus (Lautoconus) borgesi & Conidae & 15536 & NC_013243 & Cunha et al., 2009 \\
\hline Conus (Pionoconus) consors & Conidae & 16112 & NC_-023460 & Brauer et al., 2012 \\
\hline Conus (Cylinder) textile & Conidae & 15562 & NC_008797 & Bandyopadhyay et al., 2008 \\
\hline Conus (Splinoconus) tribblei & Conidae & 15570 & KT199301 & Barghi et al., 2015 \\
\hline Conus (Gastridium) tulipa & Conidae & 16599 & NC_027518 & Chen et al., 2015 \\
\hline Fusiturris similis & Clavatulidae & 15595 & NC_013242 & Cunha et al., 2009 \\
\hline Xenuroturris cerithiformis & Turridae & 15380 & NC_008098 & Bandyopadhyay et al., 2006 \\
\hline Oxymeris dimidiata & Terebridae & 16513 & NC_013239 & Cunha et al., 2009 \\
\hline
\end{tabular}

${ }^{*}$ Complete genomes 
Complementary Data 1. Amplification strategy. Long PCR and primer walking primers

Conus californicus

\begin{tabular}{llc}
$\begin{array}{l}\text { Long PCR } \\
\text { Primer }\end{array}$ & Sequence 5'-3' & Fragment (bp) \\
\hline $\begin{array}{l}\text { Forcox1F } \\
\text { Cdea16sR }\end{array}$ & AGCTTTTGACTTTTACCCCCTGCTTTG & \multirow{2}{*}{ coxl-rrnL (5346) } \\
\hline $\begin{array}{ll}\text { Forcox1R } \\
\text { Cdea16sF }\end{array}$ & GTCTACTTTGCACGGTCAGAGTACC & GrnL-cox3 (10219) \\
\hline
\end{tabular}

Primer Link rrnL

Primer

16sinicioF2 TTCTGCCTGTTTAKCAAAAACATGGCTTC

16sfinR AAAGATAATGCTGTTATCCCTRCGG

$r r n L-r r n L(425)$

Conus (Lautoconus) venulatus

\begin{tabular}{lll}
$\begin{array}{l}\text { Long PCR } \\
\text { Primer }\end{array}$ & Sequence 5'-3' & Fragment (bp) \\
\hline $\begin{array}{l}\text { Conus_cox1_F } \\
\text { Conus_16S_R }\end{array}$ & AGTTTYTGRCTTCTTCCTCCTGCGCTT & \multirow{2}{*}{ coxl-rrnL (5371) } \\
\hline Conus_12S_F & GAGATATACTACCTTTGCACGGTCAGAG & \\
Conus_nd4_R & GAATTTAGGACTACCTCCGTGATGAATAG & rrnL-coxl (6024) \\
\hline $\begin{array}{l}\text { Conus_nd4_F } \\
\text { Conus_cox1_R }\end{array}$ & GTTTATTAAGCGTACTCGTCTTTGCAGCAT & \multirow{2}{*}{ CCTAAA-coxl (5926) } \\
\hline
\end{tabular}

Conus (Lautoconus) ventricosus

\begin{tabular}{|c|c|c|}
\hline Long PCR & & \\
\hline Primer & Sequence $5^{\prime}-3^{\prime}$ & Fragment (bp) \\
\hline Conus_cox1_F & AGTTTYTGRCTTCTTCCTCCTGCGCTT & \\
\hline Conus_16S_R & GATTATGCTACCTTTGCACGGTCAGAG & $\operatorname{rnL}(5358)$ \\
\hline Conus_12S_F & GAGATAAGTCGTAACAYAGTAGGGGTAATG & $160037)$ \\
\hline Conus_nd4_R & GAATTTAGGACTACCTCCGTGATGAATAG & $\operatorname{coxi}(0051)$ \\
\hline Conus_nd4_F & GTTTATTAAGCGTACTCGTCTTTGCAGCAT & $0 \times 1(5935)$ \\
\hline Conus cox $1 \mathrm{R}$ & CCTAAAATAGAAGAHACMCCAGCAAGATG & \\
\hline
\end{tabular}

Conus (Lautoconus) hybridus

\begin{tabular}{|c|c|c|}
\hline \multicolumn{3}{|l|}{ Long PCR } \\
\hline Primer & Sequence $5{ }^{\prime}-3^{\prime}$ & Fragment $(b p)$ \\
\hline$\overline{\text { Cdeacox3F }}$ & ATGGCACGAAATCCATTTCATTTRGTTGA & \\
\hline COIbfol_R & TATAAAATDGGATCHCCACCTCCTGC & $\operatorname{cox} 3-\operatorname{cox} 1$ (3339) \\
\hline$\overline{\text { COIfol_F }}$ & TATTTTCTACHAATCATAAAGATATTGG & \\
\hline Cdea16sR & CTACCTTTGCACGGTCAGAGTACC & $\cos 1$ \\
\hline Cdea16sF & GCCTTATAATTGAAGGCTRGWATGAATGG & \\
\hline CdeaPheR & TACYTTAGCATCTTCAGCGCTAYGCTCT & ) \\
\hline
\end{tabular}

Primer Link rrnL

Primer

Sequence $5^{\prime}-3^{\prime}$

\begin{tabular}{lll}
\hline 16 sinicioF2 & TTCTGCCTGTTTAKCAAAAACATGGCTTC & rrnL-rrnL (426)
\end{tabular}

Conus (Eugeniconus) nobilis victor

\begin{tabular}{|c|c|c|}
\hline \multicolumn{3}{|l|}{ Long PCR } \\
\hline Primer & Sequence 5'-3' & Fragment (bp) \\
\hline Cdeacox3F & ATGGCACGAAATCCATTTCATTTRGTTGA & \multirow{2}{*}{$\operatorname{cox} 3-\operatorname{cox} 1$ (3397) } \\
\hline COIbfol R & TATAAAATDGGATCHCCACCTCCTGC & \\
\hline COIfol_F & TATTTTCTACHAATCATAAAGATATTGG & \multirow{2}{*}{ coxl-rrnL (5694) } \\
\hline Cdea16sR & CTACCTTTGCACGGTCAGAGTACC & \\
\hline$\overline{\text { Cdea16sF }}$ & GCCTTATAATTGAAGGCTRGWATGAATGG & \multirow{2}{*}{$r r n L-t r n F(7005)$} \\
\hline CdeaPheR & TACYTTAGCATCTTCAGCGCTAYGCTCT & \\
\hline
\end{tabular}


Primer Link rrnL

Primer

Sequence 5'-3'

16sinicioF2 TTCTGCCTGTTTAKCAAAAACATGGCTTC

16 sfinR AAAGATAATGCTGTTATCCCTRCGG

$r r n L-r r n L(427)$

Conasprella wakayamaensis

\begin{tabular}{lll}
$\begin{array}{l}\text { Long PCR } \\
\text { Primer }\end{array}$ & Sequence 5'-3' & Fragment (bp) \\
\hline Cdeacox3F & ATGGCACGAAATCCATTTCATTTRGTTGA & \multirow{2}{*}{ cox3-cox1 (3324) } \\
COIbfol_R & TATAAAATDGGATCHCCACCTCCTGC & \multirow{2}{*}{ coxl-rrnL (6282) } \\
\hline COIfol_F & TATTTTCTACHAATCATAAAGATATTGG & \\
Cdea16sR & CTACCTTTGCACGGTCAGAGTACC & rrnL-trnF (7037) \\
\hline Cdea16sF & GCCTTATAATTGAAGGCTRGWATGAATGG & \\
CdeaPheR & TACYTTAGCATCTTCAGCGCTAYGCTCT &
\end{tabular}

Primer Link rrnL

Primer

16sinicioF2 TTCTGCCTGTTTAKCAAAAACATGGCTTC

16sfinR AAAGATAATGCTGTTATCCCTRCGG

$r r n L-r r n L(445)$

Liliconus sagei

\begin{tabular}{llc}
$\begin{array}{l}\text { Long PCR } \\
\text { Primer }\end{array}$ & Sequence 5'-3' & Fragment (bp) \\
\hline Cdeacox3F & ATGGCACGAAATCCATTTCATTTRGTTGA & \multirow{2}{*}{ cox3-coxl (3863) } \\
Lilicox1R & CTGCACCTAAAATTGATGAAGCACCAGC & \\
\hline Lilicox1F & TTAAGTCAACCTGGGGCTCTGTTAGG & coxl-rrnL (5553) \\
Cdea16sR & CTACCTTTGCACGGTCAGAGTACC & \multirow{2}{*}{ rrnL-trnF (6964) } \\
\hline Cdea16sF & GCCTTATAATTGAAGGCTRGWATGAATGG & \\
CdeaPheR & TACYTTAGCATCTTCAGCGCTAYGCTCT & \\
\hline
\end{tabular}

Primer Link rrnL

Primer Sequence 5'-3'

16sinicioF2 TTCTGCCTGTTTAKCAAAAACATGGCTTC r rnL-rrnL (427)

16 sfinR AAAGATAATGCTGTTATCCCTRCGG

-rrnL (427)

Profundiconus terimachi

\begin{tabular}{llc}
$\begin{array}{l}\text { Long PCR } \\
\text { Primer }\end{array}$ & Sequence 5'-3' & Fragment (bp) \\
\hline $\begin{array}{l}\text { Cdeacox3F } \\
\text { Cdea16sR }\end{array}$ & ATGGCACGAAATCCATTTCATTTRGTTGA & \multirow{2}{*}{ cox3-rrnL (8325) } \\
\hline Cdea16sF & GCCTCTTTGCACGGTCAGAGTACC & \\
CdeaPheR & TACYTTAGCATCTTCAGCGCTAYGCTCT & rrnL-trnF (700) \\
\hline
\end{tabular}

\section{Primer Link rrnL}

Primer

Sequence 5'-3'

\begin{tabular}{lll}
\hline 16 sinicioF2 & TTCTGCCTGTTTAKCAAAAACATGGCTTC & \multirow{2}{*}{ (6snL-rrnL (426) } \\
\hline
\end{tabular}

Pseudolilliconus traillii

\begin{tabular}{llc}
$\begin{array}{l}\text { Long PCR } \\
\text { Primer }\end{array}$ & Sequence 5'-3' & Fragment (bp) \\
\hline $\begin{array}{l}\text { Cdeacox3F } \\
\text { Cdea16sR }\end{array}$ & ATGGCACGAAATCCATTTCATTTRGTTGA & \multirow{2}{*}{ cox3-rrnS (8124) } \\
\hline $\begin{array}{l}\text { Pseu12sF } \\
\text { CdeaPheR }\end{array}$ & AATCTGTTGGAACGGTCAGTTTGAGGGAAACCGGG & \multirow{2}{*}{ trnS-trnF (8175) } \\
\hline
\end{tabular}

Benthomangelia sp.

Long PCR

Primer

Sequence 5'-3'

Fragment (bp) 


\begin{tabular}{|c|c|c|}
\hline $\begin{array}{l}\text { Cdeacox3F } \\
\text { Mangcox1R }\end{array}$ & $\begin{array}{l}\text { ATGGCACGAAATCCATTTCATTTRGTTGA } \\
\text { ACAGCHCCTAAAATAGAAGAAACACC }\end{array}$ & $\operatorname{cox} 3-\operatorname{cox} 1(3065)$ \\
\hline Mangcox1F & GGAGCTCCHGATATAGTWTTTCCTCG & \multirow{2}{*}{$\operatorname{coxl-rrnL}(5261)$} \\
\hline Cdea16sR & CTACCTTTGCACGGTCAGAGTACC & \\
\hline Cdea16sF & GCCTTATAATTGAAGGCTRGWATGAATGG & \multirow{2}{*}{$r r n L-t r n F(7019)$} \\
\hline CdeaPheR & TACYTTAGCATCTTCAGCGCTAYGCTCT & \\
\hline
\end{tabular}

\section{Primer Link rrnL}

Primer

Sequence 5'-3'

16sinicioF2 TTCTGCCTGTTTAKCAAAAACATGGCTTC

16 sfinR AAAGATAATGCTGTTATCCCTRCGG

Tomopleura sp.

\begin{tabular}{llc}
$\begin{array}{l}\text { Long PCR } \\
\text { Primer }\end{array}$ & Sequence 5'-3' & Fragment (bp) \\
\hline $\begin{array}{l}\text { Cdeacox3F } \\
\text { Borcox1R }\end{array}$ & $\begin{array}{l}\text { ATGGCACGAAATCCATTTCATTTRGTTGA } \\
\text { GATATAARATAGGATCWCCRCCTCCTGC }\end{array}$ & cox3-cox1 (3299) \\
\hline $\begin{array}{l}\text { Borcox1F } \\
\text { Cdea16sR }\end{array}$ & $\begin{array}{l}\text { ATTGGAGGATTTGGRAATTGRTTRGTTCC } \\
\text { CTACCTTTGCACGGTCAGAGTACC }\end{array}$ & cox1-rrnL (5380) \\
\hline $\begin{array}{l}\text { Cdea16sF } \\
\text { BorcobR }\end{array}$ & GCCTTATAATTGAAGGCTRGWATGAATGG & \multirow{2}{*}{ GGnL-cob (3249) } \\
\hline Borcob4F & GAAGTCCCTATTCGAAAAGTTCATCCGG & \multirow{2}{*}{ cobtrnF (4737) } \\
CdeaPheR & TACYTTAGCATCTTCAGCGCTAYGCTCT & \\
\hline
\end{tabular}

Primer Link rrnL

Primer Sequence 5'-3'

16sinicioF2 $\quad$ TTCTGCCTGTTTAKCAAAAACATGGCTTC $\quad r r n L-r r n L ~(423)$

16 sfinR AAAGATAATGCTGTTATCCCTRCGG

Glyphostoma sp.

\begin{tabular}{llc}
$\begin{array}{l}\text { Long PCR } \\
\text { Primer }\end{array}$ & Sequence 5'-3' & Fragment (bp) \\
\hline $\begin{array}{l}\text { Cdeacox3F } \\
\text { Clathcox1R }\end{array}$ & ATGGCACGAAATCCATTTCATTTRGTTGA & cox3-cox1 (3145) \\
\hline Clathcox1F & GGCACCTAAAATAGAAGAAACACCNGCAAG & \\
Cdea16sR & CTACCTTTGCACGGTCAGAGTACC & $\operatorname{cox1-rrnL~(5351)}$ \\
\hline $\begin{array}{l}\text { Cdea16sF } \\
\text { Conus_nd4_R }\end{array}$ & GCCTTATAATTGAAGGCTRGWATGAATGG & \multirow{2}{*}{ GAATTTAGad4 (5147) } \\
\hline
\end{tabular}

Primer Link rrnL

Primer

Sequence 5'-3'

16sinicioF2

TTCTGCCTGTTTAKCAAAAACATGGCTTC

16 sfinR AAAGATAATGCTGTTATCCCTRCGG 
Supplementary Material 2. Best fit partitions and evolutionary substitution models as selected by Partition Finder

\begin{tabular}{|c|c|c|c|c|c|c|c|c|c|c|c|c|c|}
\hline \multicolumn{14}{|l|}{ Conidae matrix } \\
\hline \multirow{4}{*}{ Best Partition to CDS genes (BIC $=72340.71)$} & 1 atp6-8 & MtMam+l+G+F & 0.34 & 0.09 & & & & & & & & & \\
\hline & $2 c o b$ & MtArt+I+G & 0.98 & 0.54 & & & & & & & & & \\
\hline & $3 \cos 1-2-3$ & MtMam+I+G+F & 0.61 & 0.62 & & & & & & & & & \\
\hline & 4 nad1-2-3-4-4L-5-6 & MtMam+I+G+F & 0.37 & 0.10 & & & & & & & & & \\
\hline Best Partition to rARNs genes (BIC $=46628.80$ ) & $5 r r n L-S$ & $\mathrm{GTR}+\mathrm{I}+\mathrm{G}$ & 0.61 & 0.27 & 0.29 & 5.14 & 1.04 & 0.08 & 5.80 & 0.36 & 0.12 & 0.18 & 0.33 \\
\hline \multicolumn{14}{|l|}{ Conus matrix } \\
\hline & Set Partition & Best Model & Alpha & Pinvar & $A<->C$ & $A<->G$ & $A<->T$ & $C<->\mathrm{G}$ & $C<->T$ & $\operatorname{pi}(A)$ & $\mathrm{pi}(\mathrm{C})$ & $\mathrm{pi}(\mathrm{G})$ & $\mathrm{pi}(\mathrm{T})$ \\
\hline \multirow{12}{*}{ Best Partition CDS genes (BIC $=117487.53)$} & 1 atp6-8 1th & $\mathrm{HKY}+\mathrm{G}$ & 1.57 & 0.56 & 1.79 & 35.88 & 3.42 & 1.57 & 43.41 & 0.28 & 0.15 & 0.20 & 0.34 \\
\hline & 2 atp6-8 2th & $\mathrm{GTR}+\mathrm{I}+\mathrm{G}$ & 1.12 & 0.70 & 0.73 & 10.38 & 0.97 & 8.95 & 6.46 & 0.17 & 0.22 & 0.13 & 0.47 \\
\hline & 3 atp6-8 3th & $\mathrm{HKY}+\mathrm{I}+\mathrm{G}$ & 1.11 & 0.02 & 27.02 & 226.17 & 4.16 & 12.15 & 367.55 & 0.28 & 0.08 & 0.13 & 0.49 \\
\hline & 4 cob 1th & $\mathrm{GTR}+\mathrm{G}$ & 1.45 & 0.68 & 2.09 & 13.92 & 1.22 & 0.00 & 47.87 & 0.22 & 0.20 & 0.26 & 0.30 \\
\hline & 5 cob 2th & $\mathrm{GTR}+\mathrm{I}+\mathrm{G}$ & 0.77 & 0.81 & 0.00 & 2.88 & 0.69 & 4.58 & 6.03 & 0.21 & 0.21 & 0.15 & 0.41 \\
\hline & 6 cob 3th & $H K Y+I+G$ & 0.57 & 0.03 & 15.09 & 1745.51 & 4.62 & 54.55 & 1796.65 & 0.32 & 0.10 & 0.09 & 0.47 \\
\hline & 7 cox $1-2-31$ th & $\mathrm{GTR}+\mathrm{I}+\mathrm{G}$ & 0.68 & 0.65 & 0.96 & 5.93 & 0.00 & 0.00 & 33.81 & 0.23 & 0.16 & 0.31 & 0.28 \\
\hline & $8 \cos 1-2-32$ th & $\mathrm{GTR}+\mathrm{I}+\mathrm{G}$ & 1.20 & 0.89 & 1.90 & 6.12 & 0.46 & 9.23 & 3.83 & 0.19 & 0.21 & 0.18 & 0.39 \\
\hline & 9 cox $1-2-3$ th & $H K Y+G$ & 0.96 & 0.00 & 4.13 & 295.70 & 6.55 & 32.23 & 342.50 & 0.30 & 0.06 & 0.16 & 0.47 \\
\hline & 10 nad1-2-3-4-4L-5-6 1th & $\mathrm{GTR}+\mathrm{I}+\mathrm{G}$ & 0.47 & 0.27 & 3.16 & 15.82 & 1.71 & 2.01 & 40.21 & 0.28 & 0.15 & 0.21 & 0.33 \\
\hline & 11 nad1-2-3-4-4L-5-6 2th & $\mathrm{GTR}+\mathrm{I}+\mathrm{G}$ & 0.69 & 0.62 & 1.09 & 12.35 & 1.11 & 9.74 & 8.34 & 0.16 & 0.20 & 0.16 & 0.46 \\
\hline & 12 nad1-2-3-4-4L-5-6 3th & $\mathrm{GTR}+\mathrm{I}+\mathrm{G}$ & 1.65 & 0.02 & 13.47 & 256.02 & 6.36 & 25.46 & 197.03 & 0.33 & 0.10 & 0.12 & 0.42 \\
\hline Best Partition to rARNs genes (BIC $=25260.64$ ) & $13 r r n L-S$ & $\mathrm{GTR}+\mathrm{I}+\mathrm{G}$ & 0.28 & 0.06 & 0.98 & 22.03 & 3.82 & 1.24 & 23.43 & 0.35 & 0.13 & 0.19 & 0.32 \\
\hline
\end{tabular}




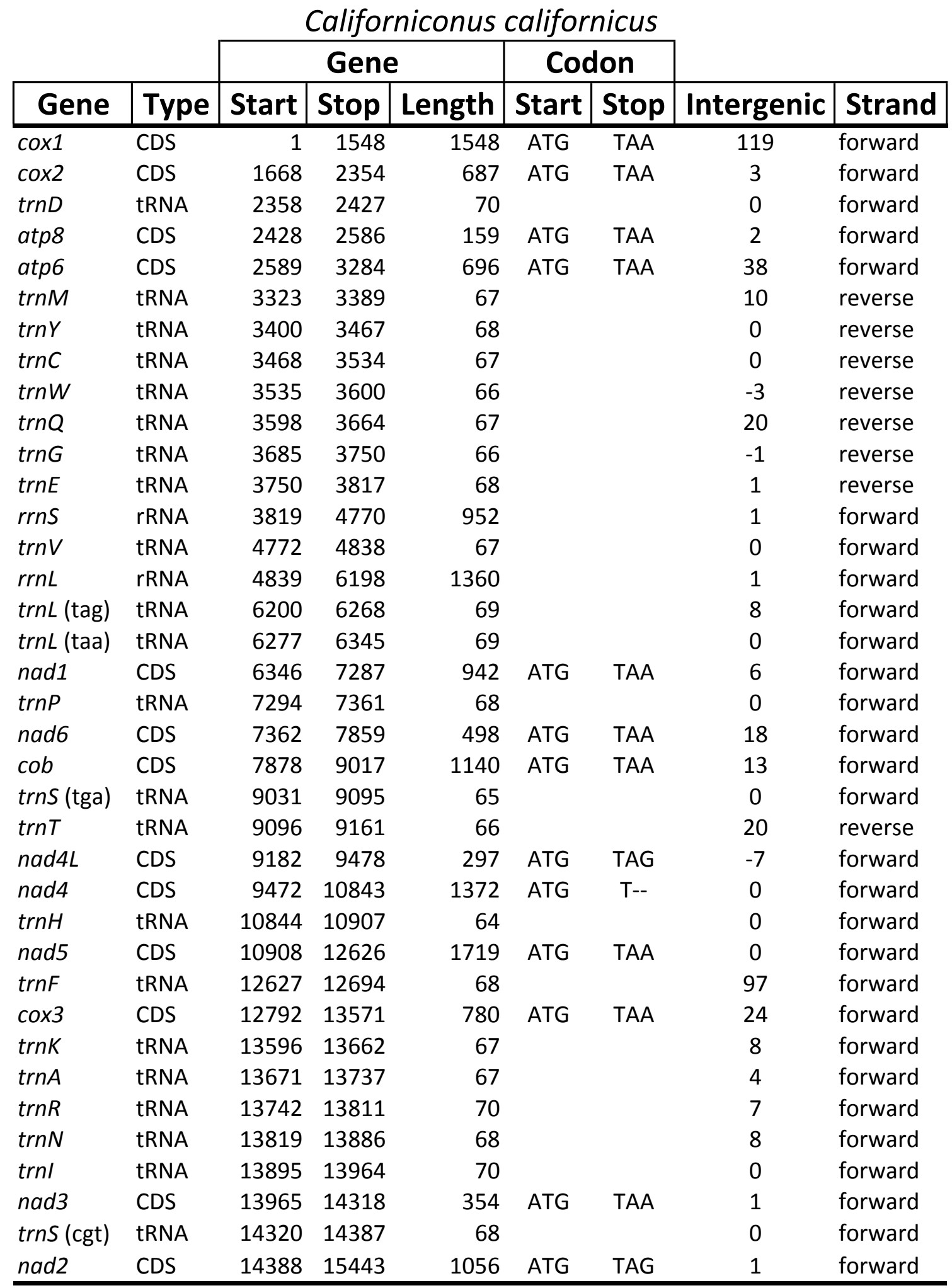




\begin{tabular}{|c|c|c|c|c|c|c|c|c|}
\hline & \multicolumn{5}{|c|}{ Conus (Lautoconus) venulatu } & \multirow[b]{3}{*}{ Intergenic } & \multirow[b]{3}{*}{ Strand } \\
\hline & & \multicolumn{3}{|c|}{ Gene } & \multicolumn{2}{|c|}{ Codon } & & \\
\hline Gene & Type & Start & Stop & Length & Start & Stop & & \\
\hline $\operatorname{cox} 1$ & CDS & 1 & 1548 & 1548 & $\overline{\text { ATG }}$ & TAA & 130 & forward \\
\hline $\cos 2$ & CDS & 1679 & 2365 & 687 & ATG & TAA & 0 & forward \\
\hline $\operatorname{trn} D$ & tRNA & 2366 & 2432 & 67 & & & 0 & forward \\
\hline atp8 & CDS & 2433 & 2594 & 162 & ATG & TAG & 6 & forward \\
\hline atp6 & CDS & 2601 & 3296 & 696 & ATG & TAA & 40 & forward \\
\hline $\operatorname{trnM}$ & tRNA & 3337 & 3404 & 68 & & & 13 & reverse \\
\hline $\operatorname{trn} Y$ & tRNA & 3418 & 3483 & 66 & & & 4 & reverse \\
\hline $\operatorname{trnC}$ & tRNA & 3488 & 3552 & 65 & & & 0 & reverse \\
\hline $\operatorname{trn} W$ & tRNA & 3553 & 3618 & 66 & & & 1 & reverse \\
\hline $\operatorname{trn} Q$ & tRNA & 3620 & 3677 & 58 & & & 14 & reverse \\
\hline $\operatorname{trnG}$ & tRNA & 3692 & 3757 & 66 & & & 1 & reverse \\
\hline $\operatorname{trn} E$ & tRNA & 3759 & 3826 & 68 & & & 0 & reverse \\
\hline$r r n S$ & rRNA & 3827 & 4781 & 955 & & & 0 & forward \\
\hline $\operatorname{trnV}$ & tRNA & 4782 & 4848 & 67 & & & 0 & forward \\
\hline$r r n L$ & rRNA & 4849 & 6212 & 1364 & & & 0 & forward \\
\hline $\operatorname{trnL}$ (tag) & tRNA & 6213 & 6282 & 70 & & & 6 & forward \\
\hline $\operatorname{trnL}$ (taa) & tRNA & 6289 & 6357 & 69 & & & 0 & forward \\
\hline nad1 & CDS & 6358 & 7299 & 942 & ATG & TAA & 3 & forward \\
\hline $\operatorname{trn} P$ & tRNA & 7303 & 7369 & 67 & & & 0 & forward \\
\hline nad6 & CDS & 7370 & 7870 & 501 & ATG & TAA & 11 & forward \\
\hline$c o b$ & CDS & 7882 & 9021 & 1140 & ATG & TAA & 12 & forward \\
\hline $\operatorname{trnS}$ (tga) & tRNA & 9034 & 9098 & 65 & & & 9 & forward \\
\hline $\operatorname{trnT}$ & tRNA & 9108 & 9174 & 67 & & & 21 & reverse \\
\hline nad4L & CDS & 9196 & 9492 & 297 & ATG & TAG & -7 & forward \\
\hline nad4 & CDS & 9486 & 10867 & 1382 & ATG & TA- & 0 & forward \\
\hline $\operatorname{trnH}$ & tRNA & 10868 & 10934 & 67 & & & 0 & forward \\
\hline nad5 & CDS & 10935 & 12649 & 1715 & ATG & TA- & 0 & forward \\
\hline $\operatorname{trnF}$ & tRNA & 12650 & 12715 & 66 & & & 126 & forward \\
\hline $\operatorname{cox} 3$ & CDS & 12842 & 13621 & 780 & ATG & TAA & 25 & forward \\
\hline $\operatorname{trnK}$ & tRNA & 13647 & 13716 & 70 & & & 4 & forward \\
\hline $\operatorname{trn} A$ & tRNA & 13721 & 13787 & 67 & & & 16 & forward \\
\hline $\operatorname{trn} R$ & tRNA & 13804 & 13872 & 69 & & & 10 & forward \\
\hline $\operatorname{trn} N$ & tRNA & 13883 & 13951 & 69 & & & 14 & forward \\
\hline trnl & tRNA & 13966 & 14035 & 70 & & & 5 & forward \\
\hline nad3 & CDS & 14041 & 14394 & 354 & ATG & TAA & 8 & forward \\
\hline $\operatorname{trnS}(\mathrm{cgt})$ & tRNA & 14403 & 14470 & 68 & & & 0 & forward \\
\hline nad2 & CDS & 14471 & 15524 & 1054 & ATG & T-- & 0 & forward \\
\hline
\end{tabular}




\begin{tabular}{|c|c|c|c|c|c|c|c|c|}
\hline & \multicolumn{7}{|c|}{ Conus (Lautoconus) ventricosus } \\
\hline & & \multicolumn{3}{|c|}{ Gene } & \multicolumn{2}{|c|}{ Codon } & \multirow[b]{2}{*}{ Intergenic } & \multirow[b]{2}{*}{ Strand } \\
\hline Gene & Type & Start & Stop & Length & Start & Stop & & \\
\hline $\operatorname{cox} 1$ & CDS & 1 & 1548 & 1548 & $\overline{\text { ATG }}$ & TAA & 130 & forward \\
\hline $\cos 2$ & CDS & 1679 & 2365 & 687 & ATG & TAA & 0 & forward \\
\hline $\operatorname{trn} D$ & tRNA & 2366 & 2432 & 67 & & & 0 & forward \\
\hline atp8 & CDS & 2433 & 2594 & 162 & ATG & TAA & 6 & forward \\
\hline atp6 & CDS & 2601 & 3296 & 696 & ATG & TAA & 35 & forward \\
\hline $\operatorname{trnM}$ & tRNA & 3332 & 3399 & 68 & & & 12 & reverse \\
\hline $\operatorname{trn} Y$ & tRNA & 3412 & 3477 & 66 & & & 1 & reverse \\
\hline $\operatorname{trnC}$ & tRNA & 3479 & 3543 & 65 & & & 0 & reverse \\
\hline $\operatorname{trn} W$ & tRNA & 3544 & 3610 & 67 & & & 1 & reverse \\
\hline $\operatorname{trn} Q$ & tRNA & 3612 & 3669 & 58 & & & 15 & reverse \\
\hline $\operatorname{trnG}$ & tRNA & 3685 & 3750 & 66 & & & 2 & reverse \\
\hline $\operatorname{trnE}$ & tRNA & 3753 & 3818 & 66 & & & 0 & reverse \\
\hline$r r n S$ & rRNA & 3819 & 4769 & 951 & & & 0 & forward \\
\hline $\operatorname{trnV}$ & tRNA & 4770 & 4837 & 68 & & & 0 & forward \\
\hline$r r n L$ & rRNA & 4838 & 6201 & 1364 & & & 0 & forward \\
\hline $\operatorname{trnL}(\operatorname{tag})$ & tRNA & 6202 & 6271 & 70 & & & 18 & forward \\
\hline $\operatorname{trnL}$ (taa) & tRNA & 6290 & 6358 & 69 & & & 0 & forward \\
\hline nad1 & CDS & 6359 & 7300 & 942 & ATG & TAG & 4 & forward \\
\hline $\operatorname{trn} P$ & tRNA & 7305 & 7372 & 68 & & & 0 & forward \\
\hline nad6 & CDS & 7373 & 7873 & 501 & ATG & TAG & 11 & forward \\
\hline$c o b$ & CDS & 7885 & 9024 & 1140 & ATG & TAG & 11 & forward \\
\hline $\operatorname{trnS}$ (tga) & tRNA & 9036 & 9100 & 65 & & & 9 & forward \\
\hline $\operatorname{trnT}$ & tRNA & 9110 & 9176 & 67 & & & 20 & reverse \\
\hline nad4L & CDS & 9197 & 9493 & 297 & ATG & TAG & -7 & forward \\
\hline nad4 & CDS & 9487 & 10868 & 1382 & ATG & TA- & 0 & forward \\
\hline $\operatorname{trnH}$ & tRNA & 10869 & 10935 & 67 & & & 0 & forward \\
\hline nad5 & CDS & 10936 & 12651 & 1716 & ATG & TAA & 10 & forward \\
\hline $\operatorname{trnF}$ & tRNA & 12662 & 12726 & 65 & & & 126 & forward \\
\hline $\operatorname{cox} 3$ & CDS & 12853 & 13632 & 780 & ATG & TAA & 23 & forward \\
\hline $\operatorname{trnK}$ & tRNA & 13656 & 13725 & 70 & & & 6 & forward \\
\hline $\operatorname{trn} A$ & tRNA & 13732 & 13797 & 66 & & & 18 & forward \\
\hline $\operatorname{trn} R$ & tRNA & 13816 & 13884 & 69 & & & 10 & forward \\
\hline $\operatorname{trn} N$ & tRNA & 13895 & 13964 & 70 & & & 9 & forward \\
\hline trnl & tRNA & 13974 & 14043 & 70 & & & 5 & forward \\
\hline nad3 & CDS & 14049 & 14402 & 354 & ATG & TAA & 8 & forward \\
\hline $\operatorname{trnS}(\mathrm{cgt})$ & tRNA & 14411 & 14478 & 68 & & & 0 & forward \\
\hline nad2 & CDS & 14479 & 15534 & 1056 & ATG & TAA & 0 & forward \\
\hline
\end{tabular}




\begin{tabular}{|c|c|c|c|c|c|c|c|c|}
\hline & \multicolumn{5}{|c|}{ Conus (Lautoconus) hybridus } & \multirow[b]{3}{*}{ Intergenic } & \multirow[b]{3}{*}{ Strand } \\
\hline & & \multicolumn{3}{|c|}{ Gene } & \multicolumn{2}{|c|}{ Codon } & & \\
\hline Gene & Type & Start & Stop & Length & Start & Stop & & \\
\hline $\operatorname{cox} 1$ & $\mathrm{CDS}$ & 2655 & 4202 & 1548 & ATG & TAA & 120 & forward \\
\hline $\cos 2$ & CDS & 4323 & 5009 & 687 & ATG & TAG & & forward \\
\hline $\operatorname{trn} D$ & tRNA & 5010 & 5076 & 67 & & & & forward \\
\hline atp8 & CDS & 5077 & 5238 & 162 & ATG & TAA & & forward \\
\hline atp6 & CDS & 5245 & 5940 & 696 & ATG & TAG & & forward \\
\hline $\operatorname{trnM}$ & tRNA & 5975 & 6042 & 68 & & & 12 & reverse \\
\hline $\operatorname{trn} Y$ & tRNA & 6055 & 6121 & 67 & & & & reverse \\
\hline $\operatorname{trnC}$ & tRNA & 6123 & 6187 & 65 & & & & reverse \\
\hline $\operatorname{trn} W$ & tRNA & 6188 & 6253 & 66 & & & & reverse \\
\hline $\operatorname{trn} Q$ & tRNA & 6251 & 6317 & 67 & & & 10 & reverse \\
\hline $\operatorname{trn} G$ & tRNA & 6328 & 6393 & 66 & & & & reverse \\
\hline $\operatorname{trn} E$ & tRNA & 6396 & 6461 & 66 & & & & reverse \\
\hline$r r n S$ & rRNA & 6462 & 7409 & 948 & & & & forward \\
\hline $\operatorname{trn} V$ & tRNA & 7410 & 7476 & 67 & & & & forward \\
\hline$r r n L$ & rRNA & 7477 & 8840 & 1364 & & & & forward \\
\hline $\operatorname{trnL}$ (tag) & tRNA & 8841 & 8910 & 70 & & & & forward \\
\hline $\operatorname{trnL}$ (taa) & tRNA & 8913 & 8981 & 69 & & & & forward \\
\hline nad1 & CDS & 8982 & 9923 & 942 & ATG & TAA & & forward \\
\hline $\operatorname{trn} P$ & tRNA & 9928 & 9994 & 67 & & & & forward \\
\hline nad6 & CDS & 9995 & 10495 & 501 & ATG & TAA & & forward \\
\hline$c o b$ & CDS & 10508 & 11647 & 1140 & ATG & TAG & & forward \\
\hline $\operatorname{trnS}$ (tga) & tRNA & 11660 & 11724 & 65 & & & & forward \\
\hline $\operatorname{trnT}$ & tRNA & 11735 & 11801 & 67 & & & & reverse \\
\hline nad4L & CDS & 11822 & 12118 & 297 & ATG & TAG & & forward \\
\hline nad4 & CDS & 12112 & 13493 & 1382 & ATG & TA- & & forward \\
\hline $\operatorname{trnH}$ & tRNA & 13494 & 13560 & 67 & & & & forward \\
\hline$n a d 5$ & CDS & 13561 & 15276 & 1716 & ATG & TAA & & forward \\
\hline coxs & CDS & $\begin{array}{c}\infty \\
1\end{array}$ & 753 & 753 & -- & TAA & & forward \\
\hline $\operatorname{trnK}$ & tRNA & 776 & 847 & 72 & & & & forward \\
\hline $\operatorname{trn} A$ & tRNA & 853 & 919 & 67 & & & & forward \\
\hline $\operatorname{trnR}$ & tRNA & 938 & 1006 & 69 & & & & forward \\
\hline $\operatorname{trn} N$ & tRNA & 1017 & 1085 & 69 & & & & forward \\
\hline trnl & tRNA & 1095 & 1164 & 70 & & & & forward \\
\hline nad3 & CDS & 1170 & 1523 & 354 & ATG & TAA & & forward \\
\hline $\operatorname{trnS}(\mathrm{cgt})$ & tRNA & 1532 & 1599 & 68 & & & & forward \\
\hline nad2 & CDS & 1600 & 2654 & 1055 & ATG & TA- & & forward \\
\hline
\end{tabular}




\begin{tabular}{|c|c|c|c|c|c|c|c|c|}
\hline & \multicolumn{7}{|c|}{ Conus (Eugeniconus) nobilis victor } \\
\hline & & \multicolumn{3}{|c|}{ Gene } & \multicolumn{2}{|c|}{ Codon } & \multirow[b]{2}{*}{ Intergenic } & \multirow[b]{2}{*}{ Stranc } \\
\hline Gene & Type & Start & Stop & Length & Start & Stop & & \\
\hline $\cos 1$ & CDS & 2701 & 4248 & 1548 & $\overline{\text { ATG }}$ & $\overline{T A A}$ & 159 & forward \\
\hline $\cos 2$ & CDS & 4408 & 5094 & 687 & ATG & TAA & 0 & forward \\
\hline $\operatorname{trn} D$ & tRNA & 5095 & 5161 & 67 & & & 0 & forward \\
\hline atp8 & CDS & 5162 & 5323 & 162 & ATG & TAG & 6 & forward \\
\hline atp6 & CDS & 5330 & 6025 & 696 & ATG & TAG & 36 & forward \\
\hline $\operatorname{trnM}$ & tRNA & 6062 & 6129 & 68 & & & 8 & reverse \\
\hline $\operatorname{trn} Y$ & tRNA & 6138 & 6206 & 69 & & & 0 & reverse \\
\hline $\operatorname{trnC}$ & tRNA & 6207 & 6270 & 64 & & & 0 & reverse \\
\hline $\operatorname{trnW}$ & tRNA & 6271 & 6336 & 66 & & & -3 & reverse \\
\hline $\operatorname{trn} Q$ & tRNA & 6334 & 6412 & 79 & & & -4 & reverse \\
\hline $\operatorname{trn} G$ & tRNA & 6409 & 6474 & 66 & & & 1 & reverse \\
\hline $\operatorname{trn} E$ & tRNA & 6476 & 6540 & 65 & & & 0 & reverse \\
\hline$r r n S$ & rRNA & 6541 & 7502 & 962 & & & 0 & forward \\
\hline $\operatorname{trnV}$ & tRNA & 7503 & 7570 & 68 & & & 0 & forward \\
\hline$r r n L$ & rRNA & 7571 & 8942 & 1372 & & & 0 & forward \\
\hline $\operatorname{trn} L$ (tag) & tRNA & 8943 & 9012 & 70 & & & 6 & forward \\
\hline $\operatorname{trnL}$ (taa) & tRNA & 9019 & 9087 & 69 & & & 0 & forward \\
\hline nad1 & CDS & 9088 & 10029 & 942 & ATG & TAA & 4 & forward \\
\hline $\operatorname{trn} P$ & tRNA & 10034 & 10100 & 67 & & & 0 & forward \\
\hline nad6 & CDS & 10101 & 10601 & 501 & ATG & TAA & 9 & forward \\
\hline$c o b$ & CDS & 10611 & 11750 & 1140 & ATG & TAA & 12 & forward \\
\hline $\operatorname{trnS}$ (tga) & tRNA & 11763 & 11827 & 65 & & & 9 & forward \\
\hline $\operatorname{trn} T$ & tRNA & 11837 & 11903 & 67 & & & 20 & reverse \\
\hline nad4L & CDS & 11924 & 12220 & 297 & ATG & TAG & -7 & forward \\
\hline nad4 & CDS & 12214 & 13595 & 1382 & ATG & TA- & 0 & forward \\
\hline $\operatorname{trnH}$ & tRNA & 13596 & 13663 & 68 & & & 0 & forward \\
\hline nad5 & CDS & 13664 & 15379 & 1716 & ATG & TAA & 0 & forward \\
\hline $\cos 3$ & CDS & 1 & 780 & 780 & -- & TAG & 31 & forward \\
\hline $\operatorname{trnK}$ & tRNA & 812 & 881 & 70 & & & 20 & forward \\
\hline $\operatorname{trn} A$ & tRNA & 902 & 968 & 67 & & & 15 & forward \\
\hline $\operatorname{trnR}$ & tRNA & 984 & 1054 & 71 & & & 9 & forward \\
\hline $\operatorname{trnN}$ & tRNA & 1064 & 1131 & 68 & & & 7 & forward \\
\hline trnl & tRNA & 1139 & 1211 & 73 & & & 4 & forward \\
\hline nad3 & CDS & 1216 & 1569 & 354 & ATG & TAG & 8 & forward \\
\hline $\operatorname{trn} S$ (cgt) & tRNA & 1578 & 1645 & 68 & & & 0 & forward \\
\hline $\operatorname{nad} 2$ & CDS & 1646 & 2700 & 1055 & ATG & TA- & 0 & forward \\
\hline
\end{tabular}


Conasprella wakayamaensis

\begin{tabular}{|c|c|c|c|c|c|c|c|c|}
\hline \multirow{2}{*}{ Gene } & \multirow[b]{2}{*}{ Type } & \multicolumn{3}{|c|}{ Gene } & \multicolumn{2}{|c|}{ Codon } & \multirow[b]{2}{*}{ Intergenic } & \multirow[b]{2}{*}{ Strand } \\
\hline & & Start & Stop & Length & Start & Stop & & \\
\hline$\overline{\operatorname{cox} 1}$ & CDS & 2639 & 4210 & \multicolumn{2}{|c|}{1572 ATG } & TAA & 734 & forward \\
\hline $\cos 2$ & CDS & 4945 & 5630 & \multicolumn{2}{|c|}{686 ATG } & TA- & 0 & forward \\
\hline $\operatorname{trn} D$ & tRNA & 5631 & 5699 & \multicolumn{2}{|c|}{69} & & 0 & forward \\
\hline atp8 & CDS & 5700 & 5858 & \multicolumn{2}{|c|}{159 ATG } & TAA & 3 & forward \\
\hline atp6 & CDS & 5862 & 6557 & \multicolumn{2}{|c|}{696 ATG } & TAA & 46 & forward \\
\hline $\operatorname{trnM}$ & tRNA & 6604 & 6670 & \multicolumn{2}{|c|}{67} & & 1 & reverse \\
\hline $\operatorname{trn} Y$ & tRNA & 6672 & 6738 & \multicolumn{2}{|l|}{67} & & 0 & reverse \\
\hline $\operatorname{trnC}$ & tRNA & 6739 & 6804 & \multicolumn{2}{|l|}{66} & & 0 & reverse \\
\hline $\operatorname{trn} W$ & tRNA & 6805 & 6870 & \multicolumn{2}{|l|}{66} & & -2 & reverse \\
\hline $\operatorname{trn} Q$ & tRNA & 6869 & 6945 & \multicolumn{2}{|l|}{77} & & -2 & reverse \\
\hline $\operatorname{trnG}$ & tRNA & 6944 & 7010 & \multicolumn{2}{|l|}{67} & & 0 & reverse \\
\hline $\operatorname{trn} E$ & tRNA & 7011 & 7077 & \multicolumn{2}{|l|}{67} & & 0 & reverse \\
\hline$r r n s$ & rRNA & 7078 & 8029 & \multicolumn{2}{|l|}{952} & & 0 & forward \\
\hline $\operatorname{trn} V$ & tRNA & 8030 & 8097 & \multicolumn{2}{|l|}{68} & & 0 & forward \\
\hline$r r n L$ & rRNA & 8098 & 9479 & \multicolumn{2}{|l|}{1382} & & 0 & forward \\
\hline $\operatorname{trnL}$ (tag) & tRNA & 9480 & 9548 & \multicolumn{2}{|l|}{69} & & 5 & forward \\
\hline $\operatorname{trnL}$ (taa) & tRNA & 9554 & 9621 & \multicolumn{2}{|l|}{68} & & 0 & forward \\
\hline nad1 & CDS & 9622 & 10563 & \multicolumn{2}{|c|}{942 ATG } & TAA & 5 & forward \\
\hline $\operatorname{trn} P$ & tRNA & 10569 & 10638 & \multicolumn{2}{|c|}{70} & & 0 & forward \\
\hline nad6 & CDS & 10639 & 11139 & \multicolumn{2}{|c|}{501 ATG } & TAG & 21 & forward \\
\hline$c o b$ & CDS & 11161 & 12300 & 1140 & ATG & TAA & 11 & forward \\
\hline $\operatorname{trnS}$ (tga) & tRNA & 12312 & 12376 & 65 & & & 1 & forward \\
\hline $\operatorname{trnT}$ & tRNA & 12378 & 12445 & 68 & & & 36 & reverse \\
\hline nad4L & CDS & 12482 & 12778 & 297 & ATG & TAG & -7 & forward \\
\hline nad4 & CDS & 12772 & 14143 & 1372 & ATG & T-- & 0 & forward \\
\hline $\operatorname{trnH}$ & tRNA & 14144 & 14208 & 65 & & & 0 & forward \\
\hline nad5 & CDS & 14209 & 15927 & 1719 & ATG & TAG & 0 & forward \\
\hline $\operatorname{cox} 3$ & CDS & 1 & 759 & 759 & --- & TAA & 24 & forward \\
\hline $\operatorname{trnK}$ & tRNA & 784 & 852 & 69 & & & 6 & forward \\
\hline $\operatorname{trn} A$ & tRNA & 859 & 925 & 67 & & & 0 & forward \\
\hline $\operatorname{trn} R$ & tRNA & 926 & 995 & 70 & & & 11 & forward \\
\hline $\operatorname{trnN}$ & tRNA & 1007 & 1077 & 71 & & & 10 & forward \\
\hline trnl & tRNA & 1088 & 1158 & 71 & & & 2 & forward \\
\hline nad3 & CDS & 1161 & 1512 & 352 & ATG & T-- & 0 & forward \\
\hline $\operatorname{trnS}(\mathrm{cgt})$ & tRNA & 1513 & 1580 & 68 & & & 0 & forward \\
\hline $\operatorname{nad} 2$ & CDS & 1581 & 2636 & 1056 & ATG & TAA & 0 & forward \\
\hline
\end{tabular}




\begin{tabular}{|c|c|c|c|c|c|c|c|c|}
\hline & \multicolumn{5}{|c|}{ Lilliconus sagei } & \multirow[b]{3}{*}{ Intergenic } & \multirow[b]{3}{*}{ Stranc } \\
\hline & & \multicolumn{3}{|c|}{ Gene } & \multicolumn{2}{|c|}{ Codon } & & \\
\hline Gene & Type & Start & Stop & Length & Start & Stop & & \\
\hline $\cos 1$ & CDS & 2964 & 4511 & 1548 & ATG & TAA & & forward \\
\hline $\cos 2$ & CDS & 4584 & 5270 & 687 & ATG & TAA & & forward \\
\hline $\operatorname{trn} D$ & tRNA & 5277 & 5346 & 70 & & & & forward \\
\hline atp8 & CDS & 5347 & 5508 & 162 & ATG & TAA & & forward \\
\hline atp6 & CDS & 5518 & 6213 & 696 & ATG & TAA & & forward \\
\hline $\operatorname{trnM}$ & tRNA & 6249 & 6317 & 69 & & & & reverse \\
\hline $\operatorname{trn} Y$ & tRNA & 6318 & 6387 & 70 & & & & reverse \\
\hline $\operatorname{trnC}$ & tRNA & 6386 & 6451 & 66 & & & & reverse \\
\hline $\operatorname{trn} W$ & tRNA & 6454 & 6520 & 67 & & & & reverse \\
\hline $\operatorname{trn} Q$ & tRNA & 6518 & 6584 & 67 & & & & reverse \\
\hline $\operatorname{trnG}$ & tRNA & 6592 & 6658 & 67 & & & & reverse \\
\hline $\operatorname{trn} E$ & tRNA & 6657 & 6724 & 68 & & & & reverse \\
\hline$r r n S$ & rRNA & 6799 & 7762 & 964 & & & & forward \\
\hline $\operatorname{trnV}$ & tRNA & 7763 & 7831 & 69 & & & & forward \\
\hline$r r n L$ & rRNA & 7832 & 9174 & 1343 & & & & forward \\
\hline $\operatorname{trnT}$ & tRNA & 9181 & 9250 & 70 & & & & forward \\
\hline nad1 & CDS & 9317 & 10258 & 942 & ATG & TAG & & forward \\
\hline $\operatorname{trn} P$ & tRNA & 10262 & 10328 & 67 & & & & forward \\
\hline nad6 & CDS & 10329 & 10826 & 498 & ATG & TAA & & forward \\
\hline$c o b$ & CDS & 10837 & 11976 & 114 & ATG & TAA & & forward \\
\hline $\operatorname{trnS}$ (tga) & tRNA & 11977 & 12041 & 65 & & & & reverse \\
\hline nad4L & CDS & 12043 & 12339 & 297 & ATG & TAG & & forward \\
\hline nad4 & CDS & 12333 & 13701 & 1369 & GTG & T-- & & forward \\
\hline $\operatorname{trnH}$ & tRNA & 13702 & 13766 & 65 & & & & forward \\
\hline nad5 & CDS & 13767 & 15485 & 1719 & ATG & TAA & & forward \\
\hline $\cos 3$ & CDS & 1 & 756 & 756 & -- & TAA & & forward \\
\hline $\operatorname{trnK}$ & tRNA & 767 & 833 & 67 & & & & forward \\
\hline $\operatorname{trn} A$ & tRNA & 844 & 912 & 69 & & & & forward \\
\hline $\operatorname{trnN}$ & tRNA & 951 & 1017 & 67 & & & & forward \\
\hline trnl & tRNA & 1021 & 1090 & 70 & & & & forward \\
\hline nad3 & CDS & 1094 & 1447 & 354 & ATG & TAA & & forward \\
\hline $\operatorname{trnS}(\mathrm{cgt})$ & tRNA & 1449 & 1516 & 68 & & & & forward \\
\hline nad2 & CDS & 1517 & 2590 & 1074 & ATG & TAA & & forward \\
\hline $\operatorname{trnL}$ (taa) & tRNA & 2619 & 2691 & 73 & & & & forward \\
\hline $\operatorname{trnL}$ (tag) & tRNA & 2836 & 2903 & 68 & & & & forward \\
\hline
\end{tabular}




\begin{tabular}{|c|c|c|c|c|c|c|c|c|}
\hline & \multicolumn{5}{|c|}{ Profundiconus terimachi } & \multirow[b]{3}{*}{ Intergenic } & \multirow[b]{3}{*}{ Stranc } \\
\hline & & \multicolumn{3}{|c|}{ Gene } & \multicolumn{2}{|c|}{ Codon } & & \\
\hline Gene & Type & Start & Stop & Length & Start & Stop & & \\
\hline $\cos 1$ & CDS & 2636 & 4183 & 1548 & $\overline{\text { ATG }}$ & $\overline{\text { TAA }}$ & 160 & forward \\
\hline $\cos 2$ & CDS & 4344 & 5028 & 685 & ATG & T-- & 0 & forward \\
\hline $\operatorname{trn} D$ & tRNA & 5029 & 5097 & 69 & & & 0 & forward \\
\hline atp8 & CDS & 5098 & 5256 & 159 & ATG & TAA & 4 & forward \\
\hline atp6 & CDS & 5261 & 5956 & 696 & ATG & TAA & 38 & forward \\
\hline $\operatorname{trnM}$ & tRNA & 5995 & 6062 & 68 & & & 4 & reverse \\
\hline $\operatorname{trn} Y$ & tRNA & 6067 & 6133 & 67 & & & 0 & reverse \\
\hline $\operatorname{trnC}$ & tRNA & 6134 & 6199 & 66 & & & 0 & reverse \\
\hline $\operatorname{trnW}$ & tRNA & 6200 & 6265 & 66 & & & -3 & reverse \\
\hline $\operatorname{trn} Q$ & tRNA & 6263 & 6341 & 79 & & & -10 & reverse \\
\hline $\operatorname{trnG}$ & tRNA & 6332 & 6398 & 67 & & & 0 & reverse \\
\hline $\operatorname{trn} E$ & tRNA & 6399 & 6466 & 68 & & & 0 & reverse \\
\hline$r r n S$ & rRNA & 6467 & 7422 & 956 & & & 0 & forward \\
\hline $\operatorname{trnV}$ & tRNA & 7423 & 7490 & 68 & & & 0 & forward \\
\hline$r r n L$ & rRNA & 7491 & 8877 & 1387 & & & 0 & forward \\
\hline $\operatorname{trnL}$ (tag) & tRNA & 8878 & 8946 & 69 & & & 2 & forward \\
\hline $\operatorname{trnL}$ (taa) & tRNA & 8949 & 9017 & 69 & & & 0 & forward \\
\hline nad1 & CDS & 9018 & 9959 & 942 & ATG & TAG & 9 & forward \\
\hline $\operatorname{trn} P$ & tRNA & 9969 & 10035 & 67 & & & 0 & forward \\
\hline nad6 & CDS & 10036 & 10536 & 501 & ATG & TAG & 6 & forward \\
\hline$c o b$ & CDS & 10543 & 11682 & 114 & ATG & TAA & 8 & forward \\
\hline $\operatorname{trnS}$ (tga) & tRNA & 11691 & 11755 & 65 & & & 2 & forward \\
\hline $\operatorname{trn} T$ & tRNA & 11758 & 11824 & 67 & & & 15 & reverse \\
\hline nad4L & CDS & 11840 & 12136 & 297 & ATG & TAG & -7 & forward \\
\hline nad4 & CDS & 12130 & 13498 & 1369 & ATG & T-- & 0 & forward \\
\hline $\operatorname{trnH}$ & tRNA & 13499 & 13563 & 65 & & & 0 & forward \\
\hline nad5 & CDS & 13564 & 15279 & 1716 & ATG & TAA & 0 & forward \\
\hline $\cos 3$ & CDS & 1 & 771 & 771 & -- & TAA & 18 & forward \\
\hline $\operatorname{trnK}$ & tRNA & 790 & 856 & 67 & & & 8 & forward \\
\hline $\operatorname{trn} A$ & tRNA & 865 & 931 & 67 & & & 0 & forward \\
\hline $\operatorname{trnR}$ & tRNA & 932 & 1001 & 70 & & & 14 & forward \\
\hline $\operatorname{trnN}$ & tRNA & 1016 & 1081 & 66 & & & -5 & forward \\
\hline trnl & tRNA & 1077 & 1153 & 77 & & & 2 & forward \\
\hline nad3 & CDS & 1156 & 1509 & 354 & ATG & TAA & 0 & forward \\
\hline $\operatorname{trn} S$ (cgt) & tRNA & 1510 & 1577 & 68 & & & 0 & forward \\
\hline $\operatorname{nad2}$ & CDS & 1578 & 2635 & 1058 & ATG & TA- & 0 & forward \\
\hline
\end{tabular}


Pseudolilliconus traillii

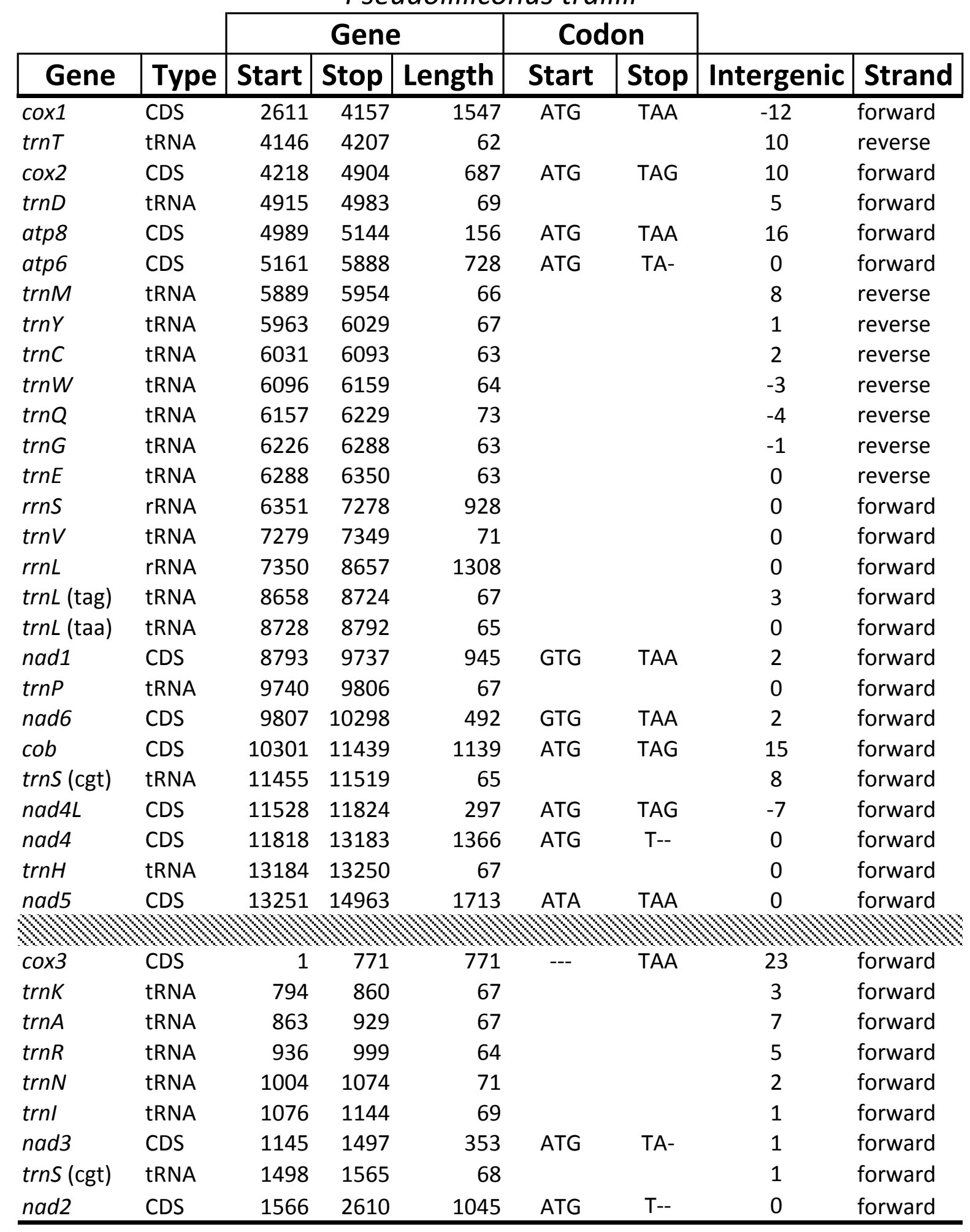


Benthomangelia sp.

\begin{tabular}{|c|c|c|c|c|c|c|c|c|}
\hline \multirow{2}{*}{ Gene } & \multirow[b]{2}{*}{ Type } & \multicolumn{3}{|c|}{ Gene } & \multicolumn{2}{|c|}{ Codon } & \multirow[b]{2}{*}{ Intergenic } & \multirow[b]{2}{*}{ Strand } \\
\hline & & Start & Stop & Length & Start & Stop & & \\
\hline $\operatorname{cox} 1$ & CDS & 2585 & 4135 & 1551 & $\overline{A T G}$ & TAA & 63 & forward \\
\hline $\cos 2$ & CDS & 4199 & 4883 & 685 & ATG & T-- & 0 & forward \\
\hline $\operatorname{trn} D$ & tRNA & 4884 & 4949 & 66 & & & 0 & forward \\
\hline atp8 & CDS & 4950 & 5108 & 159 & ATG & TAA & 2 & forward \\
\hline atp6 & CDS & 5111 & 5806 & 696 & ATG & TAG & 36 & forward \\
\hline $\operatorname{trnM}$ & tRNA & 5843 & 5909 & 67 & & & -1 & reverse \\
\hline $\operatorname{trn} Y$ & tRNA & 5909 & 5974 & 66 & & & 1 & reverse \\
\hline $\operatorname{trnC}$ & tRNA & 5976 & 6038 & 63 & & & -6 & reverse \\
\hline $\operatorname{trn} W$ & tRNA & 6033 & 6104 & 72 & & & -3 & reverse \\
\hline $\operatorname{trn} Q$ & tRNA & 6102 & 6169 & 68 & & & 3 & reverse \\
\hline $\operatorname{trnG}$ & tRNA & 6173 & 6237 & 65 & & & -1 & reverse \\
\hline $\operatorname{trn} E$ & tRNA & 6237 & 6301 & 65 & & & 0 & reverse \\
\hline$r r n S$ & rRNA & 6302 & 7252 & 951 & & & 0 & forward \\
\hline $\operatorname{trnV}$ & tRNA & 7253 & 7315 & 63 & & & 0 & forward \\
\hline$r r n L$ & rRNA & 7316 & 8649 & 1334 & & & 0 & forward \\
\hline $\operatorname{trnL}$ (tag) & tRNA & 8650 & 8715 & 66 & & & 0 & forward \\
\hline $\operatorname{trnL}$ (taa) & tRNA & 8716 & 8784 & 69 & & & 0 & forward \\
\hline nad1 & CDS & 8785 & 9726 & 942 & ATG & TAA & 8 & forward \\
\hline $\operatorname{trn} P$ & tRNA & 9735 & 9802 & 68 & & & 0 & forward \\
\hline nad6 & CDS & 9803 & 10304 & 502 & ATG & T-- & 0 & forward \\
\hline$c o b$ & CDS & 10305 & 11444 & 114 & ATG & TAA & 11 & forward \\
\hline $\operatorname{trnS}$ (tga) & tRNA & 11456 & 11520 & 65 & & & 0 & forward \\
\hline $\operatorname{trnT}$ & tRNA & 11521 & 11584 & 64 & & & 6 & reverse \\
\hline nad4L & CDS & 11591 & 11887 & 297 & ATG & TAG & -7 & forward \\
\hline nad4 & CDS & 11881 & 13252 & 1372 & ATG & T-- & 0 & forward \\
\hline $\operatorname{trnH}$ & tRNA & 13253 & 13317 & 65 & & & 1 & forward \\
\hline nad5 & CDS & 13319 & 15034 & 1716 & ATG & TAG & 0 & forward \\
\hline $\cos 3$ & CDS & 1 & 756 & 756 & --- & TAA & 11 & forward \\
\hline $\operatorname{trnK}$ & tRNA & 768 & 832 & 65 & & & 0 & forward \\
\hline $\operatorname{trn} A$ & tRNA & 833 & 899 & 67 & & & 1 & forward \\
\hline $\operatorname{trnR}$ & tRNA & 901 & 967 & 67 & & & 5 & forward \\
\hline $\operatorname{trnN}$ & tRNA & 973 & 1041 & 69 & & & 4 & forward \\
\hline trnl & tRNA & 1046 & 1112 & 67 & & & 1 & forward \\
\hline nad3 & CDS & 1114 & 1465 & 352 & ATG & T-- & 0 & forward \\
\hline $\operatorname{trnS}$ (cgt) & tRNA & 1466 & 1533 & 68 & & & 0 & forward \\
\hline $\operatorname{nad} 2$ & CDS & 1534 & 2584 & 1051 & ATG & T-- & 0 & forward \\
\hline
\end{tabular}


Tomopleura sp.

\begin{tabular}{|c|c|c|c|c|c|c|c|c|}
\hline & \multirow{2}{*}{\multicolumn{3}{|c|}{ Gene }} & \multirow{2}{*}{\multicolumn{2}{|c|}{ Codon }} & \multirow[b]{3}{*}{ Intergenic } & \multirow[b]{3}{*}{ Strand } \\
\hline & & & & & & & & \\
\hline Gene & Type & Start & Stop & Length & Start & Stop & & \\
\hline $\operatorname{cox} 1$ & $\mathrm{CDS}$ & 2615 & 4162 & \multicolumn{2}{|c|}{1548 ATG } & TAG & 44 & forward \\
\hline $\operatorname{trn} T$ & tRNA & 4207 & 4276 & \multicolumn{2}{|c|}{70} & & -2 & reverse \\
\hline $\cos 2$ & CDS & 4275 & 4959 & \multicolumn{2}{|c|}{685 ATG } & T-- & 0 & forward \\
\hline $\operatorname{trn} D$ & tRNA & 4960 & 5028 & \multicolumn{2}{|c|}{69} & & 0 & forward \\
\hline atp8 & CDS & 5029 & 5187 & \multicolumn{2}{|c|}{159 ATG } & TAA & 7 & forward \\
\hline atp6 & CDS & 5195 & 5890 & \multicolumn{2}{|c|}{696 ATG } & TAA & 36 & forward \\
\hline $\operatorname{trnM}$ & tRNA & 5927 & 5993 & \multicolumn{2}{|c|}{67} & & 3 & reverse \\
\hline $\operatorname{trn} Y$ & tRNA & 5997 & 6064 & \multicolumn{2}{|l|}{68} & & 0 & reverse \\
\hline $\operatorname{trnC}$ & tRNA & 6065 & 6129 & \multicolumn{2}{|l|}{65} & & 0 & reverse \\
\hline $\operatorname{trn} W$ & tRNA & 6130 & 6195 & \multicolumn{2}{|l|}{66} & & -3 & reverse \\
\hline $\operatorname{trn} Q$ & tRNA & 6193 & 6263 & \multicolumn{2}{|l|}{71} & & -2 & reverse \\
\hline $\operatorname{trn} G$ & tRNA & 6262 & 6326 & \multicolumn{2}{|l|}{65} & & 0 & reverse \\
\hline $\operatorname{trn} E$ & tRNA & 6327 & 6396 & \multicolumn{2}{|l|}{70} & & 0 & reverse \\
\hline$r r n S$ & rRNA & 6397 & 7347 & \multicolumn{2}{|l|}{951} & & 0 & forward \\
\hline renV & tRNA & 7348 & 7414 & \multicolumn{2}{|l|}{67} & & 0 & forward \\
\hline$r r n L$ & rRNA & 7415 & 8772 & \multicolumn{2}{|l|}{1358} & & 0 & forward \\
\hline $\operatorname{trnL}$ (tag) & tRNA & 8773 & 8841 & \multirow{2}{*}{\multicolumn{2}{|c|}{$\begin{array}{l}69 \\
69\end{array}$}} & & 5 & forward \\
\hline $\operatorname{trnL}$ (taa) & tRNA & 8847 & 8915 & & & & 0 & forward \\
\hline nad1 & CDS & 8916 & 9857 & \multicolumn{2}{|c|}{942 ATG } & TAA & 3 & forward \\
\hline $\operatorname{trn} P$ & tRNA & 9861 & 9929 & \multicolumn{2}{|c|}{69} & & 0 & forward \\
\hline nad6 & CDS & 9930 & 10430 & \multicolumn{2}{|c|}{501 ATG } & TAA & 11 & forward \\
\hline$c o b$ & CDS & 10442 & 11581 & \multicolumn{2}{|c|}{114 ATG } & TAG & 6 & forward \\
\hline $\operatorname{trnS}$ (tga) & tRNA & 11588 & 11652 & 65 & & & 84 & forward \\
\hline $\operatorname{nad} 4 \mathrm{~L}$ & CDS & 11737 & 12033 & 297 & & TAG & -7 & forward \\
\hline nad4 & CDS & 12027 & 13365 & 1339 & & TAA & 33 & forward \\
\hline $\operatorname{trnH}$ & tRNA & 13399 & 13462 & 64 & & & 1 & forward \\
\hline nad5 & CDS & 13464 & 15182 & 1719 & & TAA & 0 & forward \\
\hline$\underset{\operatorname{cox} 3}{ }$ & CDS & 1 & 756 & 756 & & TAG & 29 & forward \\
\hline $\operatorname{trnK}$ & tRNA & 786 & 855 & 70 & & & 5 & forward \\
\hline $\operatorname{trn} A$ & tRNA & 861 & 928 & 68 & & & 0 & forward \\
\hline $\operatorname{trn} R$ & tRNA & 929 & 994 & 66 & & & 0 & forward \\
\hline $\operatorname{trn} N$ & tRNA & 995 & 1063 & 69 & & & 6 & forward \\
\hline trnl & tRNA & 1070 & 1139 & 70 & & & 0 & forward \\
\hline nad3 & CDS & 1140 & 1493 & 354 & & TAA & 0 & forward \\
\hline $\operatorname{trnS}$ (cgt) & tRNA & 1494 & 1561 & 68 & & & 0 & forward \\
\hline nad2 & CDS & 1562 & 2614 & 1053 & & TAA & 0 & forward \\
\hline
\end{tabular}


Glyphostoma sp.

\begin{tabular}{|c|c|c|c|c|c|c|c|c|}
\hline & \multirow{2}{*}{\multicolumn{3}{|c|}{ Gene }} & \multirow{2}{*}{\multicolumn{2}{|c|}{ Codon }} & \multirow[b]{3}{*}{ Intergenic } & \multirow[b]{3}{*}{ Strand } \\
\hline & & & & & & & & \\
\hline Gene & Type & Start & Stop & Length & Start & Stop & & \\
\hline $\operatorname{cox} 1$ & CDS & 2672 & 4219 & 1548 & $\overline{\text { ATG }}$ & TAG & 93 & forward \\
\hline $\cos 2$ & CDS & 4313 & 4997 & 685 & ATG & T-- & 0 & forward \\
\hline $\operatorname{trn} D$ & tRNA & 4998 & 5066 & 69 & & & 0 & forward \\
\hline atp8 & CDS & 5067 & 5225 & 159 & ATG & TAG & 20 & forward \\
\hline atp6 & CDS & 5246 & 5941 & 696 & ATG & TAA & 32 & forward \\
\hline $\operatorname{trn} M$ & tRNA & 5974 & 6040 & 67 & & & 1 & reverse \\
\hline $\operatorname{trn} Y$ & tRNA & 6042 & 6109 & 68 & & & 12 & reverse \\
\hline $\operatorname{trn} C$ & tRNA & 6122 & 6186 & 65 & & & -6 & reverse \\
\hline $\operatorname{trn} W$ & tRNA & 6181 & 6254 & 74 & & & -3 & reverse \\
\hline $\operatorname{trn} Q$ & tRNA & 6252 & 6318 & 67 & & & 3 & reverse \\
\hline $\operatorname{trnG}$ & tRNA & 6322 & 6388 & 67 & & & 0 & reverse \\
\hline $\operatorname{trn} E$ & tRNA & 6389 & 6454 & 66 & & & 0 & reverse \\
\hline$r r n S$ & rRNA & 6455 & 7399 & 945 & & & 0 & forward \\
\hline $\operatorname{trnV}$ & tRNA & 7400 & 7467 & 68 & & & 0 & forward \\
\hline$r r n L$ & rRNA & 7468 & 8845 & 1378 & & & 0 & forward \\
\hline $\operatorname{trn} L$ (tag) & tRNA & 8846 & 8914 & 69 & & & 10 & forward \\
\hline $\operatorname{trnL}$ (taa) & tRNA & 8925 & 8993 & 69 & & & 0 & forward \\
\hline nad1 & CDS & 8994 & 9935 & 942 & ATG & TAA & 5 & forward \\
\hline $\operatorname{trn} P$ & tRNA & 9941 & 10009 & 69 & & & 0 & forward \\
\hline nad6 & CDS & 10010 & 10519 & 510 & ATG & TAA & 19 & forward \\
\hline$c o b$ & CDS & 10539 & 11678 & 114 & ATG & TAG & 5 & forward \\
\hline $\operatorname{trnS}(\mathrm{cgt})$ & tRNA & 11684 & 11748 & 65 & & & 0 & forward \\
\hline $\operatorname{trnT}$ & tRNA & 11749 & 11815 & 67 & & & 9 & reverse \\
\hline nad4L & CDS & 11825 & 12121 & 297 & ATG & TAG & -7 & forward \\
\hline nad4 & CDS & 12115 & 13370 & 132 & ATG & -- & 0 & forward \\
\hline $\cos 3$ & CDS & 1 & 741 & 741 & --- & TAA & 14 & forward \\
\hline $\operatorname{trnK}$ & tRNA & 756 & 820 & 65 & & & 34 & forward \\
\hline $\operatorname{trn} A$ & tRNA & 855 & 921 & 67 & & & 1 & forward \\
\hline $\operatorname{trn} R$ & tRNA & 923 & 988 & 66 & & & 17 & forward \\
\hline $\operatorname{trnN}$ & tRNA & 1006 & 1071 & 66 & & & 24 & forward \\
\hline trnl & tRNA & 1096 & 1163 & 68 & & & 4 & forward \\
\hline nad3 & CDS & 1168 & 1521 & 354 & ATG & TAG & 0 & forward \\
\hline $\operatorname{trnS}(\mathrm{cgt})$ & tRNA & 1522 & 1589 & 68 & & & 0 & forward \\
\hline nad2 & CDS & 1590 & 2642 & 1053 & ATG & TAA & 29 & forward \\
\hline
\end{tabular}




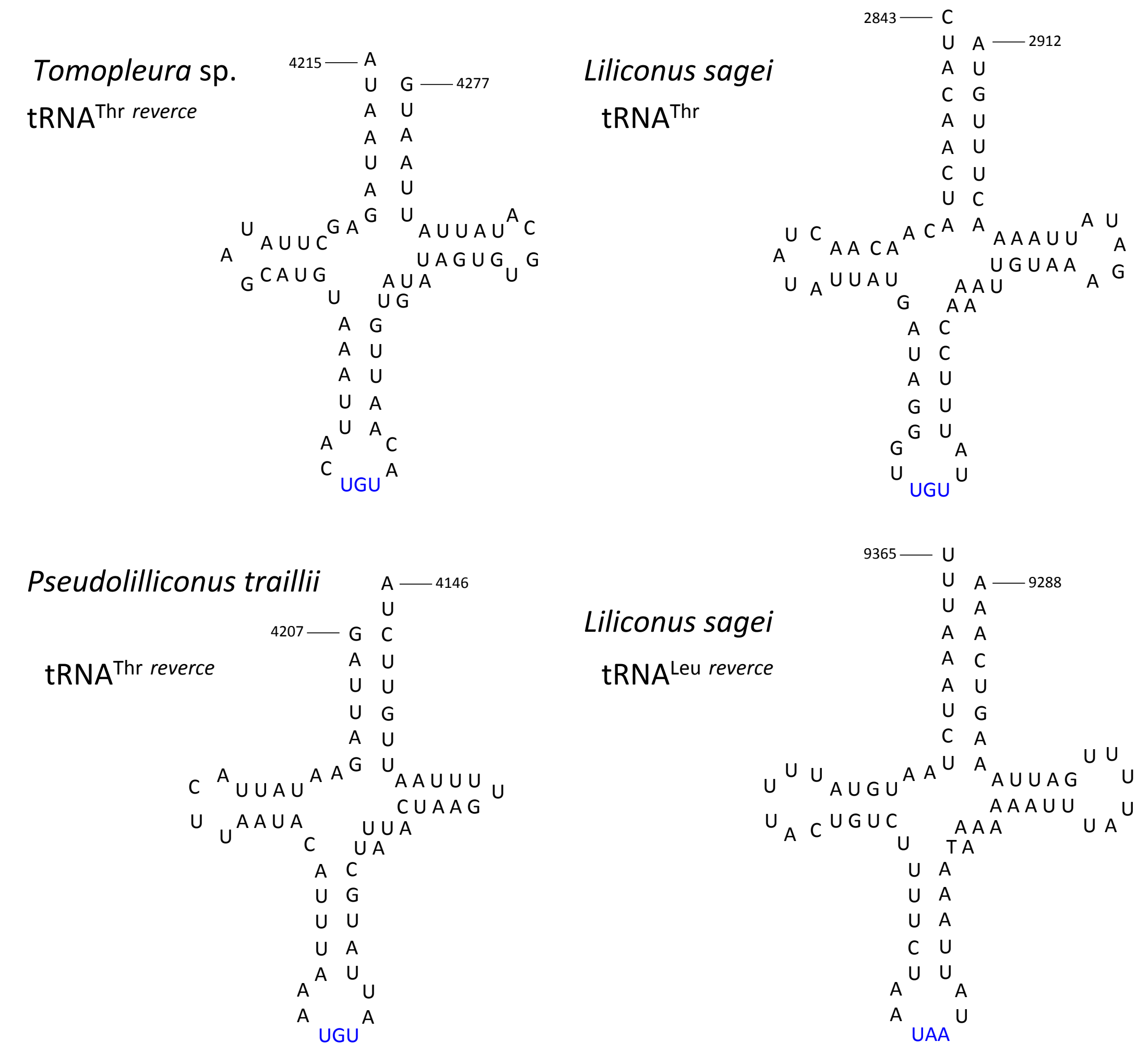

